\title{
Modelling (Social) Intra/Entrepreneurship Process
}

\author{
João M. S. Carvalho ${ }^{1,2,3 *}$ \\ ${ }^{1}$ REMIT-Universidade Portucalense, R. António Bernardino de Almeida, 4200-072 Porto, Portugal. \\ ${ }^{2}$ CICS.NOVA.UMinho, Campus de Gualtar, 4710-057 Braga, Portugal. \\ ${ }^{3}$ Centro de Estudos Globais, Universidade Aberta, 1269-001 Lisboa, Portugal.
}

\begin{abstract}
This study had three objectives: to discover the main concepts and theories used in research around entrepreneurship; systematize the entrepreneurial process in a model that allows teaching it more efficiently, and substantiate the model by applying it to various social entrepreneurship projects. To this end, a systematic scoping review was carried out to identify the main concepts, theories, and processes, which constitute the six crucial building blocks to someone could be successful as a(n) (social) intra/entrepreneur. Then, a design-science approach led us to use real social innovation and social entrepreneurship cases to evaluate the constructs and the model. Consequently, it is concluded that all concepts, theories and models identified can be classified as external factors (Context and Resources), internal factors (Objectives and entrepreneurial Will) and achievements (Action and Impact). The CROWAI model fits well with the data obtained on 465 innovation and social entrepreneurship projects. Thus, this model presents a more comprehensive approach, applicable to all profitable or social intra/entrepreneurship situations, allowing this new conceptual arrangement to be more easily taught. Additionally, it makes sense to use the term 'social' in innovation and intra/entrepreneurship because it has excellent defining power of the scope one wants to achieve with human endeavours.
\end{abstract}

Keywords:

CROWAI Model;

Entrepreneurship Process;

Social Entrepreneurship; Intrapreneurship;

Social Intrapreneurship; Corporate Social Responsibility;

Social Innovation.

\section{Article History:}

$\begin{array}{llll}\text { Received: } & 09 & \text { September } & 2021 \\ \text { Revised: } & 18 & \text { November } & 2021 \\ \text { Accepted: } & 06 & \text { December } & 2021 \\ \text { Published: } & 01 & \text { February } & 2022\end{array}$

\section{1- Introduction}

It all started with the question: why is it necessary to express social orientation in strategic management, innovation, entrepreneurship, or intrapreneurship activities? If human beings are gregarious, one would expect them to have a social impact on all their activities. Recently, this ontological doubt was expressed at a scientific meeting sponsored by the Aspen Institute Business \& Society Program and the Fetzer Institute, in which an emerging line of research related to corporate social intrapreneurship was discussed [1]. This issue is evident in the literature, clearly showing that although economic and social orientations are intricately linked, they can nevertheless lead to entrepreneurial initiatives with seemingly different focuses. One agreed with [2] when they argued that many economic or technologic innovations have social impact - one calls it 'social externalities' -, but social innovation would rather be about satisfying human and social needs that are not met by the market or by the State, which can lead to social entrepreneurship [3]. Based on social or human needs, the social entrepreneurs identify an opportunity for social business. Then, they can create a new product (good, service, idea, experience, information) that is considered a social innovation when through a(n) (social) entrepreneurial action, the novelty has success in the (social) market [4]. Thus, these reflections led us to another fundamental question: how can the entire entrepreneurial process be organized and systematized? There are contributions to theoretical modelling of the entrepreneurial [5-7] and intrapreneurial process [8], and to explain strategic

\footnotetext{
*CONTACT: joao.carvalho@upt.pt
}

DOI: http://dx.doi.org/10.28991/ESJ-2022-06-01-02

(C) 2022 by the authors. Licensee ESJ, Italy. This is an open access article under the terms and conditions of the Creative Commons Attribution (CC-BY) license (https://creativecommons.org/licenses/by/4.0/). 
entrepreneurship [9], as well as systematic literature reviews on social innovation and entrepreneurship [3, 10-12]. However, we believe that more comprehensive modelling that includes intrapreneurship and social entrepreneurship issues is lacking. Based on previous knowledge about (social) intra/entrepreneurial processes, one developed a new model with all the factors and conditions that may be in the genesis of (social) intra/entrepreneurial behaviour - context, resources, objectives, and will - as well as the role of innovation, and new approaches to entrepreneurial action and impact in society. All the constructs are interconnected and work in a permanent loop and feedback. The model is called CROWAI, the acronym for Context, Resources, Objectives, Will, Action, and Impact (Figure 1).

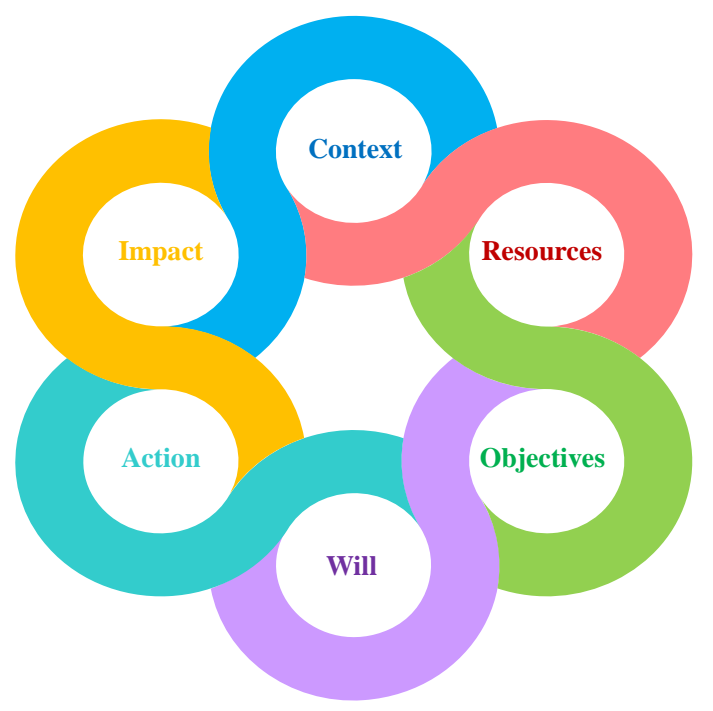

Figure 1. CROWAI model

Thus, the purpose of this paper is to present a synthetic systematic scoping review of the literature that leads to the theoretical development of the CROWAI model with the focus on social innovation and social entrepreneurship; and to test the model using a public database of social entrepreneurship projects.

\section{2- Literature Review}

This literature review is itself the result and discussion for the first objective of this study. A summary in table format is presented in the results and discussion section.

\section{2-1-Context}

The quality of the local, national, or international context that involves entrepreneurs is fundamental to the success of their ventures, being a facilitator of the entrepreneurial process [13-15]. In general, the context could also be seen as a resource, but one will deal with resources more narrowly in the next section. Román et al. [16] showed that social capital and network contact variables are strong and consistent predictors in the individual decision to start a new business. Thus, the study of networks can be included in the theme of entrepreneurial context [17]. For example, the importance of the entrepreneur's network of personal relationships is underlined by Elfring and Hulsink [18], as well as the network effect in the development of start-ups [19]. Networks can provide ideas, knowledge and material resources, and valuable new venture stakeholders [20]. More, important resources from other companies may be needed according to the Resource Dependence Theory [21,22]. All the resources that a company or an entrepreneur or social entrepreneur can obtain in its network of connections are embodied in Social Capital [23, 24]. Another approach, related to knowledge as a network resource to the entrepreneur, points to unintentional flows that go from one point to another in each network - knowledge spill-overs -, and intentional flows called knowledge transfer [25]. The Knowledge Spill-Over Theory offers new insights into discovering business opportunities and how to materialize them [26-30].

There is also a close link between an individual's networks and entrepreneurial will, which is more significant and creative if their social relationships and past knowledge and experiences are more heterogeneous [31]. More, personal networking and improvisation provide different ways of dealing with an uncertain environment in the light of the constructionist theory [32]. The crucial role that a social and industrial network plays in the success of new entrepreneurial ventures [33] can be studied using several theories [13], such as the Social Network theory [34]; Actor, Resource, and Activity theory [20, 35]; and Actor-Network Theory [36]. It is possible to notice that the interconnection between context and resources is evident in the theories of networks. More, to tap into partners' resources, organizations may have the opportunity to build Strategic Alliances with other companies or to use Open Innovation Communities $[37,38]$. 
Another approach to the network concept is that of ecosystems, developed by ecologists but adapted to organizations [39]. The concept of Business Ecosystem [40] or Entrepreneurial Ecosystem [41] or even the Territorial Innovation Models [42]: industrial districts, local production systems, etc.] can be defined as a set of economic entities, social structures, and institutions, that cooperate through a business network in an established cultural environment. In this context, it was developed the Theory of Resilience of a system, defined by the ability to experience a disturbance or change and still maintain its basic function, structure, and identity; the ability to self-organize; and the ability to increase its capacity to learn and adapt [43]. Transformations in a system's rules and dynamics can also be seen as social innovations with implications for a system's ability to change or be resilient [44]. More, the entrepreneur's sensitivity to initial conditions, which is studied, for example, in Complexity Theory [45], demonstrates that systems are nonlinear, unpredictable, and dependent on history, determining decision-making processes adaptable to different environments [46].

Within the context theme, one can also include the existence of Incubators and their impact on business venturing and idea generation [47]. There are many approaches to this subject, such as the Networked Incubator, which is a 'business incubator based on territorial synergy, relational symbiosis, and economies of scope' [48]. Other terms used in this domain are: 'Business Incubator', 'Business Accelerators', Research Parks', 'Science Parks', 'Knowledge Parks', 'Technological Parks', 'Social Innovation Parks', 'Seedbeds', 'Industrial Parks', 'Innovation Centres', and 'Technopoles'. Other authors [3] developed the Innovation Systems Theory, which aims at explaining the role of collective and interactive learning among institutions and organizations, including social innovation and the interdependency between social entrepreneurs and institutions. There are in the literature theories related to cross-sector collaboration [49] used for explaining structural developments in the knowledge-based economy [50], like the Triple Helix consisting of university-industry-government relations [51] or the Quadruple Helix, which also brings together civil society organizations [52]. In this context, the concept of Research and Development Networks also appears, which put together research projects of public institutions, private firms and government institutions [53]. Another similar approach is that of Innovation Ecosystems [54], which can be defined as nets of individuals and institutions focused on creating new products [55]. It is known that the social environment influences entrepreneurship and innovation [56, 57], and can shape organizations according to the Institutional Theory [58]. Institutions can be defined as norms, rules and beliefs in the social environment that condition organizational activity [59]. These contextual factors are entrepreneurship determinants [60] and innovation and knowledge diffusion [61]. More, institutions have shown their ability to foster or inhibit social entrepreneurship [62, 63].

On the one hand, public policies, programs, competitions, and prizes are also relevant to support entrepreneurship and innovation [64-68]. In particular, the State has a crucial role in establishing legal and tax conditions and a favourable institutional environment to promote social entrepreneurship [69]. On the other hand, strict public regulation can limit the development or commercialization of innovative products even if they are beneficial for society [70].

An entrepreneur can find and, perhaps, create a business and/or an intervention opportunity, both internally, within an organization, and externally, designing a new organization [71, 72]. As such, they can be seen as embedded agents [73], surrounded by a set of institutions that provides them with the opportunity to take part in an entrepreneurial process or socioeconomic agency [74]. It is defended that the appearance or identification of entrepreneurship or intrapreneurship opportunities is an event that happens within the context that surrounds an entrepreneur [e.g., 75]. Additionally, as proposed by the behavioural entrepreneurship theory [76], there may be a positive entrepreneurial posture based on internal, external, and strategic variables that allow the active search for new business opportunities with economic and social impact. Social entrepreneurs can also be considered an outcome of their social environment, and their endeavours as a part of a social network [77].

There are contextual motivations for social entrepreneurship within profitable companies that can be seen at the core of a corporate social responsibility strategy or as social intrapreneurship. Still, primarily social entrepreneurs create organizations in the so-called third sector. This sector exists due to the market system and the State failures to protect, support, and satisfy all social and individual needs $[64,78]$. This sector represents non-profit organizations, in which there is no appropriation of the surplus generated by the organization [78], with an impersonal heritage in favour of a particular purpose or mission. More recently, it appeared a new hybrid sector (fourth sector) composed of organizations (social enterprises) and business models that intersect the public, private and social sectors [79, 80], seeking to address social problems through business ventures [81].

Finally, entrepreneurs who have in their environment the opportunity to attend entrepreneurial education from primary school until university courses or professional training may have a greater possibility and willingness to be a(n) (social) intra/entrepreneur [82, 83].

In conclusion, many theories explain why (social) intra/entrepreneurs are conditioned and stimulated by the context. Thus, one defines the context as the social, organizational, institutional, educational, and personal networks that contribute to (social) intra/entrepreneur's availability and willingness to create new products, projects, or organizations. 


\section{2-2-Resources}

The scope of the 'resources' construct is related to the ability of an entrepreneur to mobilize physical (e.g., raw materials, equipment), human (managers and workers), intellectual (intangible assets: trademark, copyright, trade secrets, contracts, and patents), and financial resources [84]. The resource-based view theory [85] is the most used in the literature of organizations to explain their success based on processes of internal accumulation, management and distribution of resources [86]. Thus, the entrepreneurs can see their ventures as a bundle of resources and capabilities that may be difficult to imitate [87]. Intangible resources are also presented in the literature in the context of invisible as sets [88], internal competitive advantages [89], sustained competitive advantages [21], core competencies [90], dynamic capabilities [91], knowledge [92], market orientation [93], innovativeness [94], ability to innovate [95], or absorptive capacity [96]. There are dozens of theories and models that can help entrepreneurs to manage their resources efficiently and effectively. Thus, one highlights some of them that have been used in many studies: value chain analysis [97]; strategic planning [98]; Trade-Off and Pecking Order theories [99]; and transformational and transactional leadership theory [100].

Therefore, this approach sees resources in a more restricted way, as everything the entrepreneur needs to produce economic, social, ecological, or psychological value. The study of Kim et al. [101] argued that the most critical resource for being an entrepreneur is human capital, particularly when they have advanced education and managerial experience. Another study [102] presented knowledge management as the main drive behind the set of organizational competencies. Other approaches [103, 104] defended that human knowledge, structural, and relational capabilities are included in the concept of intellectual capital. All these concepts are competencies that are essential contributions to the entrepreneur's objectives through innovation and to the entrepreneurial will. Several approaches to market orientation [93, 105] include the organizational learning concept, which may enhance entrepreneurial characteristics at the individual level, promoting an entrepreneurial climate in organizations and intrapreneurship [106]. Entrepreneurs can make flexible use of resources, depending on their goals and the need to be competitive and thriving in the market or society [85, 87]. Thus, one defines resources as the physical, human, intellectual, and financial building blocks that allow entrepreneurs to develop their projects.

\section{2-3-Objectives}

The 'objectives' construct is related to the goals that entrepreneurs aim to achieve, depending on the context and available resources. Any new project, to be successful, must have competitive advantages, which can be gained in terms of product, price, distribution, communication, processes, people, partners, and/or organization's purposes [107]. Thus, one is talking about innovation, which should have societal sustainability concerns, i.e., economic, social, ecological, and psychological balance of human life [108], as a requirement of current consumers. Consequently, (social) innovation can also lead to new business models, new projects within an organization, or new (social) organizations. It presents definitions of innovation, social innovation, business model, value proposition, societal sustainability, corporate social responsibility, entrepreneurship, social entrepreneurship, intrapreneurship, and social intrapreneurship, as possible leading entrepreneurs' goals.

Based on the works of several authors [98, 108-111], innovation is defined as the generation and ability to change or adapt new products (goods, services, ideas, information, experiences) or processes so that organizations can successfully advance, compete and differentiate themselves in the market, preparing the future through an interactive process involving formal and informal relationships between various actors in a network.

Beyond technological, business, and digital innovation, the focus is social innovation, which can be defined as the creation of new solutions (ideas, activities, processes, goods, services) that are successful in solving social problems, often with limited resources, seeking for political recognition, financial support, voluntary labour, and philanthropic commitment. In this perspective, social innovation includes concepts such as socio-ecological innovation or sustainable innovation $[112,113]$ because the cause of ecological and social sustainability cannot today be removed from the concerns of people and organizations. Many for-profit organizations also engage in social innovation, namely through their corporate social responsibility activities or because they have been designed to serve a social purpose [114]. Some social innovations can be incremental, while others are radical or disruptive, promoting social change [115], transforming approaches and situations, like those targeting new customers in the low-income markets [116].

There are other specific approaches related to frugal innovation [117], inclusive innovation [118, 119], and responsible innovation [120], which are included in the concept of social innovation. The first can be seen as a strategy to reduce costs, concentrate the products on core functionalities, and meet the minimum performance level, to achieve the most affordable prices [121] for the poor, namely the consumers of the Base of the Pyramid countries [122]. This type of consumer can also benefit from inclusive innovations that create or enhance opportunities to improve their wellbeing [123]. In this context, Pilková et al. [124] presented the concept of inclusive entrepreneurship that represents a goal of a social entrepreneur, who helps individuals from vulnerable populations to overcome their state of poverty and/or social exclusion. Many strategies facilitate the creation of social innovation as an objective for the (social) intra/entrepreneur, but this theme is beyond the focus of this paper. 
Mirvis and Googins [75] presented an attractive model (corporate social innovation spectrum) that shows the continuum between social value and economic value, passing through the blended value, including socio-commercial innovation. The concept of social design also exists, which consists of a tailor-made approach to the needs of marginal groups or minorities [125]. One can also have innovation in the way one develops a business, i.e., the objective could be a new business model, which in the case of non-profit organizations can aim to overcome the traditional lack of funds and their difficulties to grow and operate at scale [126]. Thus, based on the literature (e.g., [108, 127-132]), one defines a business model as a conceptual and operational tool that describes the value proposition offered to the stakeholders through a product (good, service, idea, experience, information), as well as the organization and coordination of critical activities, team and partners, and the design of a marketing plan to deliver that value and achieve societal sustainability.

Elkington [133] presented the three P's: people, planet, and profit - triple bottom line - as the three pillars of sustainability. This theory was enhanced by the inclusion of psychological value and psychological sustainability [128, 134]. The concept of psychological sustainability includes the concepts of mental and subjective well-being, self-esteem, emotional balance, and fulfilment (e.g., new knowledge, skills, attitudes, awareness, openness, and behaviour changes), as well as a feeling of self-efficacy [135]. Thus, based on several research streams and international reports [93, 128, 134-141], one defines societal sustainability as the outcome of the contributions of all complementary aspects of sustainability: economic viability, ecological stewardship, social equity, and psychological balance.

Studies [e.g., 142, 143] showed that social-oriented companies could develop new business models to effectively and profitably address low-income markets, contributing to regional and national societal development. In general, new business models consider the role of stakeholders [144]; collaborative value creation [132, 145-147]; the creation of social and shared value [148]; and multiple value creation [127, 133].

Entrepreneurs as owners of organizations or intrapreneurs look for their businesses to show Corporate Social Responsibility (CSR) or Corporate Citizenship [149, 150]. Thus, CSR is a possible objective for (social) intra/entrepreneurs. Stewardship theory argued that managers could be good 'stewards' of an organization's assets, satisfying shareholders and stakeholders [151] and preserving its ability to survive and carry out its mission [152]. Social entrepreneurs can develop steward-based organizations whose altruistic motives can become institutionalized [153]. Stakeholder theory is commonly used in the context of other theories, and it defends that CSR decisions and activities can be beneficial for organizational performance because nonfinancial stakeholders demand them [154]. The theory of the firm also studies the impact of managers' decisions on the organizations' financial performance, namely maximization of shareholder value and, obviously, CSR decisions and activities that affect organizations' outcomes [155]. The institutional theory tries to explain how sustainability or CSR are accepted and implemented in the organizations' practices, thus becoming institutionalized [155]. Therefore, and based on many other studies (e.g., 93, $149,150,154-158]$ it is argued that an organization is social responsible if it is productive and profitable, satisfying the needs of all stakeholders; law-abiding, including paying taxes and complying with the social and ecological regulations; follows the socially established ethical standards; and, in a volunteer basis, having philanthropic activities as an additional contribution to social welfare.

Entrepreneurship, as an objective, can be defined as the process of creating a product (good, service, experience, information, or idea) or a project, frequently through an organization, to serve and satisfy human wants and needs (127, 159, 160]. Likewise, intrapreneurship may be seen as the process of recognition and exploitation of opportunities that includes the creation of new businesses related to the organization's current products, processes or markets, the design of new products and technologies, the contribution to the organization's strategy reformulation, reorganization and change, and an orientation to enhance organizational competitiveness $[8,161]$.

However, social entrepreneurship aims at enhancing social welfare, namely the sustainability for both people and the planet [162], looking for solutions to neglected problems [163] through a new combination of resources that creates social value [164-166], stimulate social change, or create new organizations [167].

In particular, the difference between a social entrepreneur and a social intrapreneur is that the former creates an organization to attend to human needs of a more social, psychological or ecological character, having the primary purpose of contributing to their resolution than making a personal profit, and viewing the stakeholders as the 'ends' and the non-profit organization or the social enterprise as the 'means' of entrepreneurship [92]. On the other hand, a social intrapreneur aims at balancing entrepreneurial profit with additional non-financial earnings within an organization [1, $72,168,169]$.

Although social innovation is embedded in any social entrepreneurial venture [170], not all social innovations imply new social organizations because they can be implemented by for-profit, non-profit enterprises or public institutions [120]. In resume, one can propose a path between four levels towards social entrepreneurship [4]: (1) there are social and human needs; (2) many of them will have a response through the creation of a product (good, service, experience, information, idea) with success in the market or society; (3) some of these products are social innovations implemented by social intra/entrepreneurs; and (4) some of them will give rise to the creation of a new organization - social entrepreneurship. 
It is concluded that an individual to be a (social) intra/entrepreneur should have, at least, one of these objectives: to create or develop a(n) (social) innovation; a new (social) business model; a unique value proposition; a way to pursuit societal sustainability; new corporate social responsibility activities; or to create or develop a new organization.

\section{2-4- Entrepreneurial Will}

The entrepreneurial will has to do with the competencies, skills, individual personality traits, the need for survival, the desire to be an entrepreneur, education for entrepreneurship, work and family background, demographic profiles, and all other individual factors that can influence a person to create and/or develop a new business or social activity. Thus, it also includes what Bird [10] called entrepreneurial intention, as a 'psychological process, state, or act of conscious willing in the present to make some experience true, realised, manifested, or created in the future. Of course, entrepreneurship will also depend on a favourable context, accessibility to the necessary resources, and determining objectives to achieve.

Several theories try to explain entrepreneurial intention. For example, the theory of reasoned behaviour [171] or planned behaviour [172] defends that intention is influenced by attitude towards the behaviour, which is controlled by an individual's choice to engage in that behaviour. Another approach is entrepreneurial event theory from Shapero and Sokol [173], which is based on examining life path changes and their impact on individual intention to create a new venture. Another one is the process-driven theory [174], based on an individual's perception of self-efficacy and external environmental factors, which shape attitude, form an intention, and lead to entrepreneurial action.

Based on the studies of many authors [44, 175, 176], a list of five crucial and general competencies and skills that an entrepreneur should develop: thinking/analysing, self-management, influencing, objective achievement, and technical.

There are other approaches, for example: Leyden et al. [31] showed that an entrepreneur is an individual who embraces uncertainty and is an innovator; Sánchez et al. [177] considered the cognitive adaptability as a key competence, being the cognitive aspects (e.g., beliefs to values, cognitive styles, mental processes) the elements that differentiate entrepreneurs from non-entrepreneurs; García [176] proposed that success depend on the level of expertise in entrepreneurial scripts (cognitive abilities); Mitchell et al. [178] considered, on the basis of the theory of expert information processing, that some cognitive scripts (arrangements, ability, and willingness) are crucial for the entrepreneurs to make assessments, judgments, or decisions involving opportunity evaluation, venture creation, and growth; Thorgren and Omorede [179] highlighted the role of leader's passion; Grimes et al. [73] defended that compassion is a fundamental motivation to encourage the entrepreneur's agency required to engage in social entrepreneurship; Paço et al. [180] studied students' entrepreneurial intention on the basis of the planned behaviour theory, underlying the importance of education and training for entrepreneurship; however, the me-ta-analysis of Van Der Sluis et al. [181] showed that higher levels of education may generate more lucrative wage employment and thus decrease the likelihood of individuals to be entrepreneurs; Brockhaus and Horwitz [182] pointed out that there is a positive relation-ship between the family background and the emergence of entrepreneurs; Smith and Woodworth [183], on the basis of social identity [184] and self-efficacy theories [135], presented an approach to social entrepreneurship education; Peterson et al. [185] indicated a positive correlation between psychological capital and innovative behaviour; Dyer et al. [186] defended that innovative entrepreneurs have creative intelligence, as they associate, question, observe, experiment and network; White et al. [187] presented the biosocial model of entrepreneurship, and concluded that new venture creation is more likely among those individuals having a higher testosterone level in combination with a family business background; Benzing et al. [188] concluded on their literature review and study that the primary reasons for starting a business depends on the country and can be resumed by the need to increase income, to obtain job and/or family security, to secure independence and autonomy, the existence of intrinsic and extrinsic rewards, and the challenge and achievement of personal satisfaction; Akehurst et al. [189] concluded that job satisfaction and commitment to the team have a positive effect on intrapreneurship; Papagiannidis et al. [190] presented in their literature review evidence that human capital, including prior knowledge and work experience, provides individuals with increases in their cognitive abilities, which is positively associated with new business creation; Hartog et al. [191] showed that general ability has a stronger impact on entrepreneurial incomes than on wages, being mathematical, social, and technical ability more valuable for entrepreneurs, who achieve higher income because they have a more balanced set of the various kinds of ability, supporting Jack-of-all-trades theory [192: balanced set of competencies across different fields]; Fine et al. [175] concluded that there are several personality traits that are characteristic of entrepreneurs, namely achievement motivation, risk-taking propensity, tolerance for ambiguity, perseverance, internal locus of control, interpersonal collaboration, autonomy and independence, openness and flexibility, and good citizen-ship; Gimmon and Levie [193] studied through a meta-analysis and on the basis of instrumental value theory [194] the impact of different human capital factors (academic titles, age, education, entrepreneurial mind-set, ethnicity, founder's team compatibility, gender, general management experience, industry-related experience, learning ability, parent(s) were entrepreneurs, and startup experience) on the performance of new ventures, concluding that all factors presented studies where they were significant and non-significant; Rathna and Vijaya [195] found out that intrapreneurs rated managerial behaviour competencies as significantly more important and frequently used than entrepreneurs, and entrepreneurs rated venturing 
behaviour competencies as significantly more important and frequently used than intrapreneurs; Hechavarria et al. [196] presented a motivational model of nascent entrepreneurial start-up outcomes based on goal setting [197] and social cognitive theory [198], concluding that having a formalized business plan and higher self-efficacy contributed to maintaining in a start-up effort versus quitting among nascent entrepreneurs; and López-Núñez et al. [199], based on Big-Five personality traits or OCEAN model, stated that the group of entrepreneurs and university students with high entrepreneurial intention have the same entrepreneurial psychological profile, which is characterized by high scores in extraversion, conscientiousness, openness to experience, emotional intelligence, self-confidence and tolerance to ambiguity and low scores in agreeableness and neuroticism.

In resume, without favourable conditions and factors predicted for the construct of entrepreneurial will, an individual could have more difficulty in being successful as a social/intra) entrepreneur. Thus, one defines the entrepreneurial will as the desire to be a(n) (social) intra/entrepreneur, based on the context, available resources, and individual objectives. However, intra/entrepreneurs also need to implement their ventures.

\section{2-5-Action}

There are several ways described in the literature about how (social) intra/entrepreneurs decided to achieve their objectives. One focus on behaviours aimed at implementing and developing entrepreneurship. Entrepreneurial action may be defined as involving 'all the functions, activities, and actions associated with perceiving opportunities and creating organizations to pursue them' [200]. In practice, there are situations where the entrepreneurial action is planned, others where it is improvised, and others where it is a consequence of past experiences [201]. These authors concluded that any approach has risks and their effects depend on entrepreneurs' choices. More, one can consider that all the views about entrepreneurial action are compatible and not mutually exclusive [202], depending on the context conditions, and can be complementary throughout the process [203].

Perrini et al. [204] proposed a model based on a process-view of social entrepreneurship, including an individual and a contextual dimension around opportunity identification, evaluation, formalization, exploitation, and scaling-up. Some several entrepreneurial methods or processes do not rely upon an overall plan. For example, the practice of a continuous effort with everyday tiny moves to achieve an objective called 'tinkering' [205] or the use of experimentation in the venture creation process [206].

Other methods have been studied in the practices of entrepreneurs, as are the cases of bricolage, bootstrapping and pivoting. Bricolage comes from an anthropological perspective [207]. What is important is 'making do', 'improvisation', and a refusal to be constrained by limitations, using the available resources to solve new problems and grasp new opportunities [208]. It could be a means for social entrepreneurs to overcome institutional restrictions [62], a way to involve the community in the cause and to achieve long-term organizational sustainability [201], and the possibility to bring existing social activities or practices to a new level [32].

Similarly, bootstrapping relies also upon improvisation with what is available to the entrepreneur [209]. It allows business operations to continue without the aid of external financial resources [210] by accessing financial capital through informal and alternative ways (e.g., obtaining advanced payments, interest on overdue invoices, avoiding customers that make late payments, delaying payments to suppliers), or minimizing or eliminating the actual need for financing (e.g., owner's financial resources, loans or credit cards, loans from family and friends, joint-utilization of resources with other firms) by securing resources at minimal or no cost [211].

Pivoting is to change organizational strategy $[212,213]$ or the business model to accommodate changes in the industry, customer preferences, or any other factor that may impact the objectives. This approach happens many times in the early days because the entrepreneur is still learning with the market response [214]. Ries [213] and Blank [212] presented pivoting and the minimum viable product in the context of the concept of lean start-up, which defends the principle of avoiding waste. To build ideas into products, measure how customers respond, and then learn whether to pivot or persevere are fundamental activities of an entrepreneur. Thus, all the activities that do not contribute to learning about the clients are a waste. The lean start-up favours experimentation, customer feedback, and iterative design over traditional planning approaches [212].

However, the non-planning approach that has been more successful in the literature is effectuation [215]. This explanation for the entrepreneurial process considers that entrepreneurs usually cope with resource-constrained environments where they have to maximize the use of resources at hand, such as abilities, expertise and networks. Organizational objectives evolve based on available resources and entrepreneurial imagination [201,216). They defend that causal logic is not suited for entrepreneurship processes inherently characterized by uncertainties and risks. Sarasvathy [215] presented five principles of the effectuation process: entrepreneurs can create their opportunities (pilotin-the-plane) and solutions with the available resources (bird-in-hand), considering that mistakes and surprises are inevitable and can be used to look for new opportunities (lemonade principle), that entering into new partnerships can bring new funds and directions to the venture (crazy quilt), and that they should only invest as much as they are willing 
to lose (affordable loss). A recent paper [217] presents a deep discussion about environmental uncertainty types and strategies associated with those different settings. It seems that the more strongly an entrepreneur perceives a problem to be ill-structured, the more that entrepreneur might prefer non-causal logics, particularly effectuation, over causal logics.

Nonetheless, as defended by many authors [93, 127, 218], planning is necessary when an entrepreneur wants to achieve specific goals and needs resources that will be affordable if the business is successful. When it is required to raise financial capital, apply to governmental funds, attract new partners, or scale up the company, it is vital to present some predicted facts and figures to gather the needed support. For that purpose, it is necessary to design a business plan. This approach is called causation, as the entrepreneur's rational decision process is based on the principles of opportunity recognition, evaluation, and exploitation [160]. McMullen and Dimov [201] argued that a causal approach is essential for a successful organization but should not come too early. It could prevent the community from becoming involved in the entrepreneurial project. The idea is to collect everything good for the social project through an open innovation process [219] involving the community and/or target people [220]. Lubberink et al. [120] defended that social innovation is only considered as responsible when the innovation process is based on public participation and deliberation. More, as Balta et al. [221] argued, adopting an entrepreneurial orientation with a market-oriented strategy provides the potential for sustainability and growth of social enterprises. Thus, entrepreneurial and market orientations are also innovative processes that contribute to the fulfilment of social missions and the success of the organizations [108].

In resume, all entrepreneurial processes are helpful to be successful, depending on the stage of the business, the context faced by the entrepreneurs, and the objectives they want to achieve in each moment.

\section{2-6-Impact}

Cieslik [11] pointed out that one of the significant concerns in social entrepreneurship is economic sustainability. Social ventures need to be effective and sustainable in practices that preserve or enhance economic, social, ecological, and psychological well-being [134, 222]. Additionally, one is aware that social intrapreneurs impact not only organizational results but also society by creating shared value [148].

Many variables (e.g., entrepreneurial orientation, market orientation, social innovation, social capital, human capital, social value, internal capabilities, external networks, corporate social responsibility) seems to have a positive impact on the financial performance and survival of start-up businesses and social organizations [223, 224]. Other studies found that the benefits of participating in socially relevant activities within companies include personal and job satisfaction and enhancing competencies like problem-solving and leadership skills [225]. More, entrepreneurs can create employment, increase territories' wealth, and contribute to productivity growth [226, 227]. Social economy and social entrepreneurship can positively affect regional development and social inclusion [159, 228].

It is possible to notice in the literature [93, 229-232] that several models can be applied to assess the organizational performance and impact, such as the Balanced Scorecard, REQI (results, efficiency, quality, and innovation), COSI (core organizational stakeholder impact), Balanced value matrix, Social impact for local economies (SIMPLEs), Potential for social value frame method, etc. In resume, the impact is defined as the outcomes and results obtained by the (social) intra/entrepreneurial process at the economic, ecological, social, and psychological levels.

Thus, we conclude through this scoping review that there is a gap in the literature related to the non-existence of modelling of the entrepreneurial process that covers its various forms, social or profitable, internal or external to organizations, and that can include all concepts, theories and models that are currently being developed in scientific research. Hence the proposal of the CROWAI model, which capitalizes on all this evolution, and broadly covers all these aspects.

\section{3- Methods}

Several systematic literature reviews have been on social innovation and entrepreneurship [e.g., 3, 10-12]. However, the specific target for our literature review led us to choose a systematic scoping review as the most appropriate method to interpret and synthesise international research about the concepts and theories around the entrepreneurship process, social entrepreneurship, intrapreneurship, social intrapreneurship, corporate social responsibility, and social innovation [233]. We followed the path of Arksey and O'Malley's [234] methodological framework for scoping reviews, with a five-phase approach: (1) developing a research question; (2) systematically identifying relevant studies; (3) charting the data; and (4) and (5) collating and analysing the results.

Our scoping review was guided by the research question: how can the entire entrepreneurial process be organized and systematized in a simple model, including the main concepts and theories? In the second and third phases, we systematically identified relevant studies by developing a search protocol that has included eight databases: Academic Search Complete, Elsevier, Journal Citation Reports, Sage, Springer, Taylor \& Francis, Web of Science, and Wiley. The search terms adopted as keywords were: 'entrepreneur* process' OR 'social entrepreneurship' OR 'intrapreneurship' OR 'social intrapreneurship' OR 'corporate social responsibility' OR 'social innovation'. Of course, there are thousands of 
papers about these topics. It was decided to find a manageable number of articles for the initial review, which was discovered by combining two, or three by three, fixing the keyword 'entrepreneur* process' and adding the others. We decided to start the review with the most recent articles on each topic. Then, a snowball approach was taken, following backwards in time the concepts and theories related to the study topics. When we reached a stage of conceptual saturation, verified by the repetition of concepts or theories, we decided to close the literature review (Table 1). Then, in the fourth and five phases, it was decided what concepts and theories are more developed in the literature, trying to synthesise all the findings in the literature review for this paper. This work allowed the theoretical development of the CROWAI model as the second purpose of the study.

Table 1. Systematic scoping review process

\begin{tabular}{lc}
\hline \multicolumn{1}{c}{ Process phases } & Total number of references \\
\hline Database records - search all terms & 127,804 \\
Database records - the boolean phrase & 49,886 \\
Database records - scientific journals & 41,377 \\
Scientific articles since 2019 & 14,120 \\
Combinations of 'entrepreneur* process' and one or two other keywords & 52 \\
Articles reviewed in the process & 312 \\
\hline
\end{tabular}

The third purpose led us to use a research method based on a design-science approach [235] with the theoretical substantiation of CROWAI model constructs, using actual cases of social innovation and social entrepreneurship to evaluate both outputs. We used public data from the 'Portugal Social Innovation' initiative that aims to promote social innovation and boost the social investment market in Portugal (https://inovacaosocial.portugal2020.pt/en/aboutus/portugal-inovacao-social/). It is a pioneering experience in Europe, as Portugal is the only Member State that has reserved part of the Community funds until 2020 to try new financing instruments that aim to foster innovation and social investment (around 150 million euros from the European Social Fund). Its goals are to promote innovation and social entrepreneurship as a way to generate new solutions to social problems, to streamline the social investment market, create financing instruments that are more suited to the specific needs of the social economy sector, and to capacitate the actors of the innovation and social entrepreneurship system in Portugal, improving the response levels of social economy entities and contributing to their economic and financial sustainability.

Portugal Social Innovation manages four financing instruments aimed at supporting the development of social innovation projects. Each of the four instruments is oriented towards a specific stage in the life cycle of social innovation projects. There also is the participation of one or more social investors (public or private entities that accompany or cofinance projects). The financing of each project is approved upon submission of organizations' applications within the scope of annual open calls. All data is available online on the site of the project.

\section{4- Results and Discussion}

As mentioned before, the result of the scoping review is synthesised in the literature review and Table 2.

Table 2. Constructs, concepts, theories, and models

\begin{tabular}{lll}
\hline Model constructs & \multicolumn{1}{c}{ Concepts } & \multicolumn{1}{c}{ Theories and Models } \\
\hline & Social networks & Social network theory \\
Stakeholders & Actor, resource, and activity - ARA model \\
& Incubators & Actor-network theory - ANT \\
& Public policies, programmes, and prizes & Resource dependence theory \\
& Public regulation & Institutional theory \\
Intrapreneurial opportunities & Complexity theory \\
& Entrepreneurial opportunities & Social capital theory \\
Societal needs & Innovation systems theory \\
Social environment & Agency theory \\
& Institutions & Stakeholder theory \\
Business ecosystems & Knowledge spill-over theory \\
& Innovation ecosystems & Knowledge transfer theory \\
& Territorial innovation models & Business ecosystem model \\
R \& D networks & Environmental uncertainty theory \\
& Strategic alliances & Resilience theory \\
Open innovation communities & Behavioural entrepreneurship model \\
& Education for entrepreneurship & Triple and Tetra helix models \\
& Third sector & Social constructionist theory \\
Fourth sector & Market and State failures theory \\
\hline
\end{tabular}




\begin{tabular}{|c|c|c|}
\hline Resources & $\begin{array}{l}\text { Physical resources } \\
\text { Human capital } \\
\text { Human resources } \\
\text { Intellectual capital } \\
\text { Intellectual resources } \\
\text { Financial resources } \\
\text { Intangible resources } \\
\text { Invisible assets } \\
\text { Internal competitive advantages } \\
\text { Sustained competitive advantages } \\
\text { Core competencies } \\
\text { Dynamic capabilities } \\
\text { Knowledge management } \\
\text { Market orientation } \\
\text { Organizational learning } \\
\text { Innovativeness } \\
\text { Ability to innovate } \\
\text { Absorptive capacity } \\
\text { Strategic planning }\end{array}$ & $\begin{array}{l}\text { Resource-based view theory } \\
\text { Knowledge management theory } \\
\text { Core competencies theory } \\
\text { Dynamic capabilities theory } \\
\text { Human capital theory } \\
\text { Intellectual capital theory } \\
\text { Market orientation model } \\
\text { Organizational learning theory } \\
\text { Innovativeness theory } \\
\text { Value chain theory } \\
\text { Strategic planning model } \\
\text { Trade-off theory } \\
\text { Pecking order theory } \\
\text { Transformational and transactional leadership theory }\end{array}$ \\
\hline Objectives & $\begin{array}{l}\text { Innovation } \\
\text { Social innovation } \\
\text { Entrepreneurship } \\
\text { Intrapreneurship } \\
\text { Corporate social responsibility } \\
\text { Social entrepreneurship } \\
\text { Social intrapreneurship } \\
\text { Inclusive entrepreneurship } \\
\text { Societal sustainability } \\
\text { Business model } \\
\text { Value proposition }\end{array}$ & $\begin{array}{l}\text { Innovation and differentiation theory } \\
\text { Societal sustainability theory } \\
\text { Business model innovation theory } \\
\text { Tetrad-value theory } \\
\text { Triple-bottom line theory } \\
\text { Social change theory } \\
\text { Frugal innovation theory } \\
\text { Inclusive innovation theory } \\
\text { Responsible innovation theory } \\
\text { The base of the pyramid theory } \\
\text { Disruptive innovation theory } \\
\text { Stakeholder theory } \\
\text { Collaborative value creation theory } \\
\text { Shared value theory } \\
\text { Corporate social responsibility theory } \\
\text { Agency theory } \\
\text { Institutional theory } \\
\text { Theory of the firm } \\
\text { The resource-based view of the firm } \\
\text { Stewardship theory } \\
\text { Stakeholder theory }\end{array}$ \\
\hline Will & $\begin{array}{l}\text { Entrepreneurial intention } \\
\text { Thinking/analysing competencies } \\
\text { Self-management competencies } \\
\text { Influencing competencies } \\
\text { Objective achievement competencies } \\
\text { People and group management competencies } \\
\text { Technical competencies } \\
\text { Entrepreneurial education } \\
\text { Family background } \\
\text { Emotional intelligence } \\
\text { Leadership } \\
\text { Cognitive scripts } \\
\text { Psychological capital } \\
\text { Social capital } \\
\text { Human capital }\end{array}$ & $\begin{array}{l}\text { Entrepreneurial competencies and skills theory } \\
\text { Emotional intelligence theory } \\
\text { Transformational leadership theory } \\
\text { Cognitive ability theory } \\
\text { Expert information processing theory } \\
\text { Environmental uncertainty theory } \\
\text { Agency theory } \\
\text { Compassion theory } \\
\text { Planned or reasoned behaviour theory } \\
\text { Self-efficacy theory } \\
\text { Social identity theory } \\
\text { Psychological capital theory } \\
\text { Social capital theory } \\
\text { Entrepreneurship biosocial theory } \\
\text { Human capital theory } \\
\text { Jack-of-all-trades theory } \\
\text { Personality traits theory } \\
\text { Big-five theory } \\
\text { Instrumental value theory } \\
\text { Goal-setting theory } \\
\text { Social cognitive theory } \\
\text { Entrepreneurial event theory } \\
\text { Process-driven theory }\end{array}$ \\
\hline
\end{tabular}




\begin{tabular}{|c|c|c|}
\hline Action & $\begin{array}{l}\text { Entrepreneurial process } \\
\text { Causation } \\
\text { Effectuation } \\
\text { Design thinking } \\
\text { Experimentation } \\
\text { Tinkering } \\
\text { Bricolage } \\
\text { Bootstrapping } \\
\text { Pivoting }\end{array}$ & $\begin{array}{l}\text { Planned behaviour theory } \\
\text { Process-based view of (social) entrepreneurship } \\
\text { Agency theory } \\
\text { Tinkering approach theory } \\
\text { Causation theory } \\
\text { Effectuation theory } \\
\text { Experimentation theory } \\
\text { Bricolage theory } \\
\text { Bootstrapping theory } \\
\text { Pivoting theory }\end{array}$ \\
\hline Impact & $\begin{array}{l}\text { Efficiency } \\
\text { Effectiveness } \\
\text { Economic sustainability } \\
\text { Social Sustainability } \\
\text { Ecological sustainability } \\
\text { Psychological sustainability } \\
\text { Quality of life } \\
\text { Financial performance } \\
\text { Territorial development }\end{array}$ & $\begin{array}{l}\text { Societal sustainability theory } \\
\text { The resource-based view of the firm theory } \\
\text { Social capital theory } \\
\text { Human capital theory } \\
\text { Self-efficacy theory } \\
\text { Social change theory } \\
\text { Social inclusion theory } \\
\text { Regional development theory }\end{array}$ \\
\hline
\end{tabular}

Previous models of the entrepreneurial process presented a more narrow approach based on the creation of a new venture across four dimensions, namely the entrepreneur, the type of organization created, the environment, and the new venture process [6], or privileging the role of the entrepreneur and new value creation within an open system related to the environment and time [5]. Another model related to strategic entrepreneurship [9] presented an input-output process that includes environmental factors, organizational and individual resources, creating value, competitive advantages, and societal, organizational and individual benefits. Additionally, Moroz and Hindle [218] presented Sarasvathy's dynamic model of effectuation as an entrepreneurial process model. Still, we consider that this model is about a particular stage of all processes, essentially related to an existing entrepreneur's means, actions and goals. In the intrapreneurship field [e.g., 8], we can notice a model that includes the role of the individual (characteristics, attitudes, and behaviours), the organizational factors, and the impact on organizational performance. Thus, the model proposed in this article manages to extend the entire process to six crucial building blocks for someone to become an entrepreneur, which is not achieved in such a comprehensive way with the existing models. This model has the advantage of clarifying exogenous and endogenous factors and ways to realize entrepreneurial will and its societal impacts. Furthermore, it updates and includes the main concepts, theories and models that have been developed in research.

Now, it will be presented an analysis of all the social organizations that won an idea competition and, as such, obtained public funding in the last two years. This analysis will illustrate how the CROWAI model allows us to explain the different phases of the entrepreneurial process. So far, no project has yet been approved for the 'social innovation fund', but two calls are already open. This funding tool facilitates access to credit and co-invest in organizations involved in social innovation and social entrepreneurship projects, thereby addressing the lack of financing solutions for the specific needs of these types of projects. Table 3 shows the distribution of projects by the four types of financing for this social innovation and entrepreneurship program.

Table 3. Distribution of projects by type of financing

\begin{tabular}{ccccc}
\hline & Capacity building for social investment & Partnerships for impact & Social impact bonds & Total \\
\hline Citizenship and community & 7 & 11 & 0 & 18 \\
Education & 21 & 41 & 7 & 69 \\
Employment & 25 & 24 & 2 & 51 \\
Digital inclusion & 0 & 6 & 0 & 6 \\
Social inclusion & 99 & 105 & 1 & 205 \\
Social innovation incubators & 0 & 20 & 0 & 20 \\
Justice & 1 & 5 & 1 & 7 \\
Health & 48 & 40 & 1 & 89 \\
Total & $\mathbf{2 0 1}$ & $\mathbf{2 5 2}$ & $\mathbf{1 2}$ & $\mathbf{4 6 5}$ \\
\hline
\end{tabular}

Source: Portugal Social Innovation site: https://inovacaosocial.portugal2020.pt/projetos/ 
The other three instruments are:

(1) Capacity building for social investment, which directly supports the implementing organization for developing teams' organizational and management skills involved in the implementation of social innovation projects. It also incentives to training consultancy, in the organization itself, with co-creation of knowledge. Payment is made for previously contracted output and not for reimbursement of expenses.

(2) Partnerships for impact, which supports the creation, implementation and growth of social innovation projects, ensuring $70 \%$ of net financing needs and $30 \%$ guaranteed by private or public social investors.

(3) Social impact bonds, which finances innovative projects aimed at obtaining social results and efficiency gains in priority areas of public policy, in the fields of Employment, Social Protection, Education, Health or Justice. Payment is made depending on the results: contracting of measurable social results. The application is made through a partnership between the Implementing Entity (which carries out the project), the Social Investors (which finance the project) and the Public Entity (which validates the alignment of the project with public policy and the relevance of the results to be contracted). If the results previously contracted are achieved, the Social Investors are fully reimbursed.

Analysing all the projects that were approved for funding, one can notice that they can be framed within the CROWAI model. First, all the projects were designed based on the context. Many of the concepts predicted on this construct are present. It started to exist a public program to promote social innovation with public regulation. There are intrapreneurial and entrepreneurial opportunities based on societal needs in a particular social environment; otherwise, there would be no substance for social intervention projects. The concept of territorial innovation models can also be seen in the way the program was divided into five regions (North, Centre, Lisbon, Alentejo, and Algarve), leading entrepreneurs to think locally in terms of social networks, institutions, stakeholders, and strategic alliances (other associations, foundations, other social economy entities, banks and insurance companies, other companies, universities, municipalities and intermunicipal entities, other public entities), what can be considered their business or innovation ecosystems. It is not possible to verify the existence of R \& D networks. Still, the support of several public and private universities in many projects allows us to think that many social interventions will target research and further development by formed consortia. All regions have entrepreneurship education at the university level, professional schools, incubators, and municipal support offices. The data does not allow us to confirm the existence of open innovation communities because it misses the history of the development of the social innovation idea. Finally, in addition to projects in the third sector, and because many of them presuppose social investment partnerships, there are also many hybrid organizations in the fourth sector.

Second, the resources' construct is evident because the entrepreneurs applied for financing to obtain the necessary resources to implement their projects. Data about the 'capacity building for social investment' in the years of 2017 and 2018 show the do-mains in which funding was requested that are present in descending order of importance: marketing, communication and fundraising $(81 \%-73.7 \%)$; Impact assessment $(60.7 \%-66.7 \%)$; strategies, partnerships and growth $(62.5 \%-51.5 \%)$; value creation model (49.4\% - 46.5\%), structure, governance, leadership and human resources $(56.5 \%$ - 32.3\%); operations and information technology management $(50.6 \%-32.3 \%)$; and financial management and risk control $(32.1 \%-34.3 \%)$. This program aims at financing the needed resources for new social innovation and social entrepreneurship projects. In addition to financial, intangible resources are the most chosen by entrepreneurs, encompassing most concepts used in the context of this construct.

Third, this program has goals that match the objectives of social intra/entrepreneurs involved in the applications. The intra/entrepreneurs proposed social innovation and entrepreneurship projects, being the majority (around 63\%) validated and approved, including new value propositions and business models, corporate social responsibility, namely by the partners, inclusive entrepreneurship, and societal sustainability.

Fourth, there is a strong entrepreneurial will because the competition for this program requires many planning actions, negotiating partnerships, and studying social problems. Thus, all the concepts included in this construct may be present. However, data do not present the profile of the entrepreneurs because the unit of analysis is the implementing entities: Associations, Houses of Mercy, Social and Parish Centres, Foundations, Cooperatives, and Institute of Religious Organization. However, there are, of course, entrepreneurs behind organisations, without whom there would be no entrepreneurship.

Fifth, the action construct is about the way entrepreneurs do things to implement their ventures. In this context, entrepreneurs used a causation approach because they needed to compete in the program, which required a structured plan about the idea, its development, implementation, and impact. However, the other entrepreneurial processes should be used, namely by the projects that were not approved. These entrepreneurs will possibly rely on improvisation, adaptation to the lack of resources, and/or adjustment of their strategies, using effectuation, experimentation, bricolage, bootstrapping or pivoting approaches; otherwise, they will give up their projects. 
Finally, the sixth construct is 'impact'. All approved projects had to be very realistic in presenting the expected impacts, and the experts considered that they had this estimated merit. Looking to the impact areas of the projects, namely citizenship and community, education, employment, digital inclusion, social inclusion, social innovation incubators, justice, and health (Table 1), it is possible to verify their pertinence and importance to societal sustainability.

\section{5- Conclusion}

This study aimed to substantiate six constructs or building blocks through a systematic scoping review, covering the fundamental aspects for an entrepreneur to succeed. It is argued that if they have the context and resources adjusted to their entrepreneurial goals, their willpower will suffice for an entrepreneurial process to take place and positively impact society. Consequently, it is proposed a model called CROWAI that resumes these aspects of the entrepreneurship process: Context, Resources, Objectives, Will, Action, and Impact. Each construct includes the main concepts and theories referred on the literature. Finally, we used social innovation and social entrepreneurship cases to confirm that the model could be a simple and good framework for describing all phases of the entrepreneurial process. The CROWAI model makes a valuable contribution to the practice of (social) intra/entrepreneurship because it presents an alignment that facilitates the development of new ventures and the practical teaching of this area of knowledge.

Returning to the initial rhetorical question (why is it necessary to express social orientation in the activities of strategic management, innovation, entrepreneurship, or intrapreneurship?), for everything we study, it seems to be essential to maintain the designation of social innovation and social entrepreneurship, since it is evident that there are differences between these concepts and the similar ones related to business. In our opinion, when one refers to something that has a social concern in the first place, one immediately imagines that it is an organization of the third sector, at most of the hybrid sector. The forms of financing and income of these organizations present particular issues, often challenging to resolve. In addition to this, there is a significant difference in the fact that if a company goes bankrupt, it is because it had no market, so it was not economically sustainable. But if it is a social organization, which can also fail due to lack of resources, the object of its activity remains; that is, the social problem does not disappear in society. Finally, the use of the social aim in corporate social responsibility, as well as in intrapreneurship, has the same raison d'être, which may imply a decrease in income for the owner or shareholder of the company in the first phase, but also an increase in productivity and business by increasing its reputation as a company concerned with social issues, which often becomes a competitive advantage in the developed world.

This study has some limitations, namely that it is impossible to refer here all the existing literature around the concepts and theories presented. For future research, it is proposed to use the CROWAI model in other sectors to increase its substantiation. Finally, one hopes that this model will help researchers, teachers, and practitioners to develop their work and action plan.

\section{6- Declarations}

\section{6-1-Author Contributions}

Conceptualization, methodology, validation, formal analysis, investigation, resources, data curation, writingoriginal draft preparation, writing - review and editing, visualization, supervision, project administration, and funding acquisition, J.M.S.C. The author has read and agreed to the published version of the manuscript.

\section{6-2-Data Availability Statement}

The data presented in this study are openly available in https://inovacaosocial.portugal2020.pt/projetos/.

\section{6-3- Funding}

This work is financed by national funds through FCT - Foundation for Science and Technology, I.P., within the scope of the project «UIDB/05105/2020» of REMIT - Research on Economics, Management and Information Technologies.

\section{6-4-Acknowledgements}

We would like to thank everyone connected to the 'Portugal Inovação Social' project for their exceptional work in fostering social innovation, allowing many organizations to make their contribution to improving the living conditions of the target populations, as well as for the fact that makes their data publicly available.

\section{6-5- Conflicts of Interest}

The author declare that there is no conflict of interests regarding the publication of this manuscript. In addition, the ethical issues, including plagiarism, informed consent, misconduct, data fabrication and/or falsification, double publication and/or submission, and redundancies have been completely observed by the author. 


\section{7- References}

[1] McGaw, N., \& Malinsky, E. (2020). Unlocking the Potential of Corporate Social Intrapreneurship: A Call to Scholars. In SSRN Electronic Journal. doi:10.2139/ssrn.3577762.

[2] Phills, J. A., Deiglmeier, K., \& Miller, D. T. (2008). Rediscovering social innovation. Stanford Social Innovation Review, Fall, 34-43. Available online: http://www.sdgrantmakers.org/members/downloads/PhillsSan Diego-Social Innovation.pdf (accessed on 10 July 2021).

[3] Phillips, W., Lee, H., Ghobadian, A., O’Regan, N., \& James, P. (2015). Social Innovation and Social Entrepreneurship: A Systematic Review. Group and Organization Management, 40(3), 428-461. doi:10.1177/1059601114560063.

[4] Carvalho, J. M. S. (2017). Social innovation and entrepreneurship: The case of porto region. In L. C. Carvalho (Ed.), Entrepreneurship: Concepts, Methodologies, Tools, and Applications (Vols. 2-4, pp. 850-887). IGI Global. doi:10.4018/978-15225-1923-2.ch036.

[5] Bruyat, C., \& Julien, P. A. (2001). Defining the field of research in entrepreneurship. Journal of Business Venturing, 16(2), 165180. doi:10.1016/S0883-9026(99)00043-9.

[6] Gartner, W. B. (1985). A Conceptual Framework for Describing the Phenomenon of New Venture Creation. The Academy of Management Review, 10(4), 696. doi:10.2307/258039.

[7] Shane, S. A general theory of entrepreneurship: The individual-opportunity nexus. Edward Elgar Publishing; Cheltenham, U.K.

[8] Neessen, P. C. M., Caniëls, M. C. J., Vos, B., \& de Jong, J. P. (2019). The intrapreneurial employee: toward an integrated model of intrapreneurship and research agenda. International Entrepreneurship and Management Journal, 15(2), 545-571. doi:10.1007/s11365-018-0552-1.

[9] Hitt, M. A., Ireland, R. D., Sirmon, D. G., \& Trahms, C. A. (2011). Strategic Entrepreneurship: Creating Value for Individuals, Organizations, and Society. Academy of Management Perspectives, 25(2), 57-75. doi:10.5465/amp.25.2.57.

[10] Bird, B. (2015). Entrepreneurial intentions research: A review and outlook. International Review of Entrepreneurship, 13(3), 143-168.

[11] Cieslik, K. (2018). The quandaries of social entrepreneurship studies-a discursive review of the discipline. Review of Social Economy, 76(3), 352-376. doi:10.1080/00346764.2018.1463446.

[12] Tan, L. P., Le, A. N. H., \& Xuan, L. P. (2020). A Systematic Literature Review on Social Entrepreneurial Intention. Journal of Social Entrepreneurship, 11(3), 241-256. doi:10.1080/19420676.2019.1640770.

[13] Baraldi, E., Havenvid, M. I., Linné, Å., \& Öberg, C. (2019). Start-ups and networks: Interactive perspectives and a research agenda. Industrial Marketing Management, 80, 58-67. doi:10.1016/j.indmarman.2018.02.002.

[14] Kelley, D., S. Singer, and M. Herrington. (2017) “Global Entrepreneurship Monitor 2015/16 - Global Report 2016.” Available online: http://www.gemconsortium.org/report/49480 (accessed on 10 July 2017).

[15] Welter, F. (2011). Contextualizing Entrepreneurship - Conceptual Challenges and Ways Forward. Entrepreneurship: Theory and Practice, 35(1), 165-184. doi:10.1111/j.1540-6520.2010.00427.x.

[16] Román, C., Congregado, E., \& Millán, J. M. (2013). Start-up incentives: Entrepreneurship policy or active labour market programme? Journal of Business Venturing, 28(1), 151-175. doi:10.1016/j.jbusvent.2012.01.004.

[17] Slotte-Kock, S., \& Coviello, N. (2010). Entrepreneurship research on network processes: A review and ways forward. Entrepreneurship: Theory and Practice, 34(1), 31-57. doi:10.1111/j.1540-6520.2009.00311.x.

[18] Elfring, T., \& Hulsink, W. (2007). Networking by entrepreneurs: Patterns of tie-formation in emerging organizations. Organization Studies, 28(12), 1849-1872. doi:10.1177/0170840607078719.

[19] Aaboen, L., Dubois, A., \& Lind, F. (2013). Strategizing as networking for new ventures. Industrial Marketing Management, 42(7), 1033-1041. doi:10.1016/j.indmarman.2013.07.003.

[20] Håkansson, H., \& Snehota, I. (1995). Developing relationships in business networks. Routledge, London, U.K.

[21] Barney, J. (1991). Firm Resources and Sustained Competitive Advantage. Journal of Management, 17(1), 99-120. doi:10.1177/014920639101700108.

[22] Pfeffer, J., \& Salancik, G. R. (2003). The external control of organizations: A resource dependence perspective. Stanford University Press, California, United States.

[23] Adler, P. S., \& Kwon, S.-W. (2002). Social Capital: Prospects for a New Concept. The Academy of Management Review, 27(1), 17. doi:10.2307/4134367.

[24] Jenner, P., \& Oprescu, F. (2016). The Sectorial Trust of Social Enterprise: Friend or Foe? Journal of Social Entrepreneurship, 7(2), 236-261. doi:10.1080/19420676.2016.1158732. 
[25] Ko, W. W., \& Liu, G. (2015). Understanding the Process of Knowledge Spillovers: Learning to Become Social Enterprises. Strategic Entrepreneurship Journal, 9(3), 263-285. doi:10.1002/sej.1198.

[26] Audretsch, D. B., Keilbach, M. C., \& Lehmann, E. E. (2007). The Knowledge Spillover Theory of Entrepreneurship. Entrepreneurship and Economic Growth, 32, 34-59. doi:10.1093/acprof:oso/9780195183511.003.0003.

[27] Doh, S., \& Acs, Z. J. (2010). Innovation and Social Capital: A Cross-Country Investigation. Industry \& Innovation, 17(3), 241262. doi:10.1080/13662711003790569.

[28] Audretsch, D. B., \& Lehmann, E. E. (2005). Does the knowledge spillover theory of entrepreneurship hold for regions? Research Policy, 34(8), 1191-1202. doi:10.1016/j.respol.2005.03.012.

[29] Audretsch, D. B., \& Lehmann, E. E. (2017). Economic performance and the knowledge spillover theory of entrepreneurship: a comment. Journal of Technology Transfer, 42(5), 1234-1235. doi:10.1007/s10961-016-9507-2.

[30] Ferreira, J. J., Ratten, V., \& Dana, L. P. (2017). Knowledge spillover-based strategic entrepreneurship. International Entrepreneurship and Management Journal, 13(1), 161-167. doi:10.1007/s11365-016-0415-6.

[31] Leyden, D. P., Link, A. N., \& Siegel, D. S. (2014). A theoretical analysis of the role of social networks in entrepreneurship. Research Policy, 43(7), 1157-1163. doi:10.1016/j.respol.2014.04.010.

[32] Johannisson, B. (2011). Towards a practice theory of entrepreneuring. Small Business Economics, 36(2), 135-150. doi:10.1007/s11187-009-9212-8.

[33] Adams, M., Makramalla, M., \& Miron, W. (2014). Down the Rabbit Hole: How Structural Holes in Entrepreneurs' Social Networks Impact Early Venture Growth. Technology Innovation Management Review, 4(9), 19-27. doi:10.22215/timreview/828.

[34] Granovetter, M. S. (1973). The Strength of Weak Ties. American Journal of Sociology, 78(6), 1360-1380. doi:10.1086/225469.

[35] Hakanson, H. (1992). A Model of Industrial Networks, in Axelson, B. ve Easton, G. (Editors) Industrial Networks: A New View of Reality, (B. Axelsson \& G. Easton (Eds.)). Routledge, London, U.K.

[36] Latour, B. (1987). Science in action: How to follow scientists and engineers through society. Harvard university press, Cambridge, USA.

[37] Dahlander, L., \& Magnusson, M. (2008). How do Firms Make Use of Open Source Communities? Long Range Planning, 41(6), 629-649. doi:10.1016/j.lrp.2008.09.003.

[38] Shaikh, M., \& Levina, N. (2019). Selecting an open innovation community as an alliance partner: Looking for healthy communities and ecosystems. Research Policy, 48(8), 103766. doi:10.1016/j.respol.2019.03.011.

[39] Hazenberg, R., Bajwa-Patel, M., Mazzei, M., Roy, M. J., \& Baglioni, S. (2016). The role of institutional and stakeholder networks in shaping social enterprise ecosystems in Europe. Social Enterprise Journal, 12(3), 302-321. doi:10.1108/sej-102016-0044.

[40] Moore, J. F. (1993). Predators and Prey: a new Ecology of Competition. Harvard Business Review, 71(3), 75-86.

[41] Roundy, P. T., Brockman, B. K., \& Bradshaw, M. (2017). The resilience of entrepreneurial ecosystems. Journal of Business Venturing Insights, 8, 99-104. doi:10.1016/j.jbvi.2017.08.002.

[42] Moulaert, F., \& Sekia, F. (2003). Territorial innovation Models: A Critical Survey. Regional Studies, 37(3), $289-302$. doi:10.1080/0034340032000065442.

[43] Walker, B., \& Salt, D. (2006). Resilience Thinking: Sustaining Ecosystems and People in a Changing World. In Peace and Conflict. Island Press.

[44] Moore, M. L., \& Westley, F. (2011). Surmountable chasms: Networks and social innovation for resilient systems. Ecology and Society, 16(1), 5. doi:10.5751/ES-03812-160105.

[45] Nunn, R. J. (2007). Complexity theory applied to itself. E:CO, Emergence: Complexity and Organization, 9(1-2), 93-106.

[46] Westley, F., Antadze, N., Riddell, D. J., Robinson, K., \& Geobey, S. (2014). Five Configurations for Scaling Up Social Innovation: Case Examples of Nonprofit Organizations from Canada. Journal of Applied Behavioral Science, 50(3), $234-260$. doi:10.1177/0021886314532945.

[47] Ebbers, J. J. (2014). Networking Behavior and Contracting Relationships among Entrepreneurs in Business Incubators. Entrepreneurship: Theory and Practice, 38(5), 1159-1181. doi:10.1111/etap.12032.

[48] Bøllingtoft, A., \& Ulhøi, J. P. (2005). The networked business incubator - Leveraging entrepreneurial agency? Journal of Business Venturing, 20(2), 265-290. doi:10.1016/j.jbusvent.2003.12.005.

[49] Manning, S., \& Roessler, D. (2014). The Formation of Cross-Sector Development Partnerships: How Bridging Agents Shape Project Agendas and Longer-Term Alliances. Journal of Business Ethics, 123(3), 527-547. doi:10.1007/s10551-013-1853-5. 
[50] Leydesdorff, L. (2012). The Triple Helix, Quadruple Helix, ..., and an N-Tuple of Helices: Explanatory Models for Analyzing the Knowledge-Based Economy? Journal of the Knowledge Economy, 3(1), 25-35. doi:10.1007/s13132-011-0049-4.

[51] Etzkowitz, H. (2003). Innovation in innovation: The Triple Helix of university-industry-government relations. Social Science Information, 42(3), 293-337. doi:10.1177/05390184030423002.

[52] Arnkil, R., A. Järvensivu, P. Koski, and T. Piirainen. "Exploring Quadruple Helix Outlining user-oriented innovation models." (2010). Final Report on Quadruple Helix Research for the CLIQ project. Available online from: https://www.researchgate.net/profile/Robert_Arnkil/publication/265065297_Exploring_the_Quadruple_Helix/links/54045354 0cf2c48563b07829.pdf (accessed on 10 July 2021).

[53] Yokura, Y., Matsubara, H., \& Sternberg, R. (2013). R\&D networks and regional innovation: A social network analysis of joint research projects in Japan. Area, 45(4), 493-503. doi:10.1111/area.12055.

[54] Rabelo, R. J., \& Bernus, P. (2015). A holistic model of building innovation ecosystems. IFAC-PapersOnLine, 28(3), $2250-2257$. doi:10.1016/j.ifacol.2015.06.423.

[55] Durst, S., \& Poutanen, P. (2013). Success factors of innovation ecosystems: A literature review. In R. Smeds \& O. Irrmann (Eds.), CO-CREATE 2013: The Boundary-Crossing Conference on Co-Design in Innovation (pp. 27-38). Aalto University Publication series SCI-ENCE+TECHNOLOGY 15/2013, Espoo, Finland.

[56] Owen-Smith, J., \& Powell, W. W. (2004). Knowledge Networks as Channels and Conduits: The Effects of Spillovers in the Boston Biotechnology Community. Organization Science, 15(1), 5-21. doi:10.1287/orsc.1030.0054.

[57] Powell, W. W., Koput, K. W., \& Smith-Doerr, L. (1996). Interorganizational collaboration and the locus of innovation: Networks of learning in biotechnology. Administrative Science Quarterly, 41(1), 116-145. doi:10.2307/2393988.

[58] DiMaggio, P. J., \& Powell, W. W. (1983). The Iron Cage Revisited: Institutional Isomorphism and Collective Rationality in Organizational Fields. American Sociological Review, 48(2), 147. doi:10.2307/2095101.

[59] Hoffman, A. J. (1999). Institutional Evolution and Change: Environmentalism and the U.S. Chemical Industry. Academy of Management Journal, 42(4), 351-371. doi:10.5465/257008.

[60] Stephen, F. H., Urbano, D., \& Van Hemmen, S. (2005). The impact of institutions on entrepreneurial activity. Managerial and Decision Economics, 26(7), 413-419. doi:10.1002/mde.1254.

[61] Moore, M. L., Westley, F. R., \& Nicholls, A. (2012). The Social Finance and Social Innovation Nexus 1. Journal of Social Entrepreneurship, 3(2), 115-132. doi:10.1080/19420676.2012.725824.

[62] Desa, G. (2012). Resource Mobilization in International Social Entrepreneurship: Bricolage as a Mechanism of Institutional Transformation. Entrepreneurship: Theory and Practice, 36(4), 727-751. doi:10.1111/j.1540-6520.2010.00430.x.

[63] Urbano, D., Toledano, N., \& Soriano, D. R. (2010). Analyzing social entrepreneurship from an institutional perspective: Evidence from Spain. Journal of Social Entrepreneurship, 1(1), 54-69. doi:10.1080/19420670903442061.

[64] Liebman, J. B. (2013). Advancing evidence-based policymaking to solve social problems. Issues in Science and Technology, 30(1), 47-55.

[65] Patel, M. (2013). Why Contest Improve Philanthropy: Six lessons on designing public prizes for impact. In Knight Foundation Report, Miami, Florida, USA.

[66] Pitt-Catsouphes, M., Berzin, S. C., McNamara, T. K., Halvorsen, C., \& Emerman, J. (2016). The Impact of the Purpose PrizeTM: Exploring a Method to Stimulate Social Entrepreneurship. Journal of Enterprising Culture, 24(02), $133-167$. doi:10.1142/s0218495816500060.

[67] Russell, R., Atchison, M., \& Brooks, R. (2008). Business plan competitions in tertiary institutions: Encouraging entrepreneurship education. Journal of Higher Education Policy and Management, 30(2), 123-138. doi:10.1080/13600800801938739.

[68] Tjornbo, O., \& Westley, F. R. (2012). Game Changers: The Big Green Challenge and the Role of Challenge Grants in Social Innovation. Journal of Social Entrepreneurship, 3(2), 166-183. doi:10.1080/19420676.2012.726007.

[69] Kostetska, I., \& Berezyak, I. (2014). Social entrepreneurship as an innovative solution mechanism of social problems of society. Management Theory and Studies for Rural Business and Infrastructure Development, 36(3), 567-577. doi:10.15544/mts.2014.053.

[70] Paik, Y., Kang, S., \& Seamans, R. (2019). Entrepreneurship, innovation, and political competition: How the public sector helps the sharing economy create value. Strategic Management Journal, 40(4), 503-532. doi:10.1002/smj.2937.

[71] Barki, E., Comini, G., Cunliffe, A., Hart, S., \& Rai, S. (2015). Social entrepreneurship and social business: Retrospective and prospective research. RAE Revista de Administracao de Empresas, 55(4), 380-384. doi:10.1590/S0034-759020150402. 
[72] Grayson, D., McLaren, M., \& Spitzeck, H. (2017). Social intrapreneurism and all that Jazz: How business innovators are helping to build a more sustainable world. In Social Intrapreneurism and All That Jazz: How Business Innovators are Helping to Build a More Sustainable World. Greenleaf Publishing. Sheffield, U.K. doi:10.4324/9781351287760.

[73] Grimes, M. G., McMullen, J. S., Vogus, T. J., \& Miller, T. L. (2013). Studying the origins of social entrepreneurship: Compassion and the role of embedded agency. Academy of Management Review, 38(3), 460-463. doi:10.5465/amr.2012.0429.

[74] Emirbayer, M., \& Mische, A. (1998). What is agency? American Journal of Sociology, 103(4), 962-1023. doi:10.1086/231294.

[75] Mirvis, P., \& Googins, S. (2018). Engaging employees as social innovators. California Management Review, 60(4), 25-50. doi:10.1177/0008125618779062.

[76] Covin, J. G., \& Slevin, D. P. (1991). A Conceptual Model of Entrepreneurship as Firm Behavior. Entrepreneurship Theory and Practice, 16(1), 7-26. doi:10.1177/104225879101600102.

[77] Anderson, A. R., \& Miller, C. J. (2003). "Class matters": Human and social capital in the entrepreneurial process. Journal of Socio-Economics, 32(1), 17-36. doi:10.1016/S1053-5357(03)00009-X.

[78] Weisbrod, B. A. (2021). The Nonprofit Economy. In The Nonprofit Economy. Harvard University Press. doi:10.2307/j.ctv1pwnsdr.

[79] Austin, J., Stevenson, H., \& Wei-Skillern, J. (2006). Social and commercial entrepreneurship: Same, different, or both? Entrepreneurship: Theory and Practice, 30(1), 1-22. doi:10.1111/j.1540-6520.2006.00107.x.

[80] Michelini, L. (2012). Social Innovation and New Business Models: Creating Shared Value in Low-Income Markets. Springer. doi:10.1007/978-3-642-32150-4.

[81] Battilana, J., \& Lee, M. (2014). Advancing Research on Hybrid Organizing - Insights from the Study of Social Enterprises. Academy of Management Annals, 8(1), 397-441. doi:10.1080/19416520.2014.893615.

[82] Higgins, D., Smith, K., \& Mirza, M. (2013). Entrepreneurial Education: Reflexive Approaches to Entrepreneurial Learning in Practice. Journal of Entrepreneurship, 22(2), 135-160. doi:10.1177/0971355713490619.

[83] Kuratko, D. F. (2005). The emergence of entrepreneurship education: Development, trends, and challenges. Entrepreneurship: Theory and Practice, 29(5), 577-598. doi:10.1111/j.1540-6520.2005.00099.x.

[84] Carvalho, J. M. da S. (2020). Organizational Toughness Facing New Economic Crisis. European Journal of Management and Marketing Studies, 5(3), 156-176. doi:10.46827/ejmms.v5i3.873.

[85] Penrose, E. (1959). The theory of the growth of the firm Blackwell. London, UK.

[86] Wright, P. M., Dunford, B. B., \& Snell, S. A. (2001). Human resources and the resource based view of the firm. Journal of Management, 27(6), 701-721. doi:10.1177/014920630102700607.

[87] Beltran-Martín, I., Roca-Puig, V., Escrig-Tena, A., \& Bou-Llusar, J. C. (2009). Internal labour flexibility from a resource-based view approach: Definition and proposal of a measurement scale. International Journal of Human Resource Management, 20(7), 1576-1598. doi:10.1080/09585190902985194.

[88] Itami, H., \& Roehl, T. W. (1987). Mobilizing Invisible Assets. In Mobilizing Invisible Assets. Harvard University Press. doi:10.4159/9780674038981.

[89] Grant, R. M. (1991). The Resource-Based Theory of Competitive Advantage: Implications for Strategy Formulation. California Management Review, 33(3), 114-135. doi:10.2307/41166664.

[90] Hamel, G., \& Prahalad, C. K. (1990). The core competence of the corporation. Harvard business review, 68(3), 79-91.

[91] Teece, D., \& Pisano, G. (1994). The dynamic capabilities of firms: An introduction. Industrial and Corporate Change, 3(3), 537556. doi:10.1093/icc/3.3.537-a.

[92] Nonaka, I., \& Takeuchi, H. The knowledge-creating company. Oxford University Press.

[93] Carvalho, J. M. S. Innovation \& Entrepreneurship. Idea, Information, Implementation, Impact.

[94] Avlonitis, G. J., Kouremenos, A., \& Tzokas, N. (1994). Assessing the Innovativeness of Organizations and its Antecedents: Project Innovstrat. European Journal of Marketing, 28(11), 5-28. doi:10.1108/03090569410075812.

[95] Hurley, R. F., \& Hult, G. T. M. (1998). Innovation, market orientation, and organizational learning: An integration and empirical examination. Journal of Marketing, 62(3), 42-54. doi:10.2307/1251742.

[96] Cohen, W. M., \& Levinthal, D. A. (1990). Absorptive Capacity: A New Perspective on Learning and Innovation. Administrative Science Quarterly, 35(1), 128. doi:10.2307/2393553.

[97] Porter, M. E., \& Advantage, C. (1985). Creating and sustaining superior performance. Competitive advantage, 167, 167-206. 
[98] Carvalho, J. M. S. Planeamento Estratégico - O seu guia para o sucesso "Strategic Planning. Your guide to success". Grupo Editorial Vida Económica.

[99] López-Gracia, J., \& Sogorb-Mira, F. (2008). Testing trade-off and pecking order theories financing SMEs. Small Business Economics, 31(2), 117-136. doi:10.1007/s11187-007-9088-4.

[100] Bass, B. M., Avolio, B. J., \& Atwater, L. (1996). The transformational and transactional leadership of men and women. Applied Psychology, 45(1), 5-34. doi:10.1111/j.1464-0597.1996.tb00847.x.

[101] Kim, P. H., Aldrich, H. E., \& Keister, L. A. (2006). Access (not) denied: The impact of financial, human, and cultural capital on entrepreneurial entryin the United States. Small Business Economics, 27(1), 5-22. doi:10.1007/s11187-006-0007-x.

[102] Gloet, M., \& Terziovski, M. (2004). Exploring the relationship between knowledge management practices and innovation performance. Journal of Manufacturing Technology Management, 15(5), 402-409. doi:10.1108/17410380410540390.

[103] Edvinsson, L., \& Malone, M. S. (1997). Intellectual capital: The proven way to establish your company's real value by finding its hidden brainpower. Piatkus.

[104] Stewart, T. A. (1997). Intellectual capital: the new wealth of organizations, Bantam Doubleday Dell Publishing Group. Inc., New York, NY.

[105] Sinkula, J. M., Baker, W. E., \& Noordewier, T. (1997). A framework for market-based organizational learning: Linking values, knowledge, and behavior. Journal of the Academy of Marketing Science, 25(4), 305-318. doi:10.1177/0092070397254003.

[106] Nasution, H. N., Mavondo, F. T., Matanda, M. J., \& Ndubisi, N. O. (2011). Entrepreneurship: Its relationship with market orientation and learning orientation and as antecedents to innovation and customer value. Industrial Marketing Management, 40(3), 336-345. doi:10.1016/j.indmarman.2010.08.002.

[107] Carvalho, J., \& Marnoto, S. (2016). The 8P Innovation \& Differentiation Model. Obrazovanje Za Poduzetništvo - E4E: Znanstveno Stručni Časopis o Obrazovanju Za Poduzetništvo, 6(2), 7-17.

[108] Carvalho, J. M. S. (2017). Social Innovation, Entrepreneurship, and Sustainability. In L. C. Carvalho (Ed.), Handbook of Research on Entrepreneurial Ecosystems and Social Dynamics in a Globalized World (pp. 147-180). IGI Global. doi:10.4018/978-1-5225-3525-6.ch007.

[109] Baregheh, A., Rowley, J., \& Sambrook, S. (2009). Towards a multidisciplinary definition of innovation. Management Decision, 47(8), 1323-1339. doi:10.1108/00251740910984578.

[110] Doh, S., \& Acs, Z. J. (2010). Innovation and social capital: A cross-country investigation. Industry and Innovation, 17(3), 241262. doi:10.1080/13662711003790569.

[111] Euchner, J. (2014). Ten Types of Innovation: The Discipline of Building Breakthroughs. In Research-Technology Management (Vol. 57, Issue 5). John Wiley \& Sons.

[112] Edgeman, R., \& Eskildsen, J. (2013). Socio-Ecological Innovation: Strategic Integration of Innovation for Sustainability and Sustainable Innovation. In Proceedings of the 10th International European Conference on Intangibles and Intellectual Capital, Knowledge Management \& Organizational Learning, 114-123.

[113] Olsson, P., \& Galaz, V. (2013). Social-Ecological Innovation and Transformation. In Nicholls \& A. Murdoch (Eds.), Social Innovation. Palgrave MacMillan. doi:10.1057/9780230367098.0018.

[114] Dees, J. G., \& Anderson, B. B. (2003). For-profit social ventures. International Journal of Entrepreneurship Education, 2(1), 126.

[115] Edwards-Schachter, M. E., Matti, C. E., \& Alcántara, E. (2012). Fostering Quality of Life through Social Innovation: A Living Lab Methodology Study Case. Review of Policy Research, 29(6), 672-692. doi:10.1111/j.1541-1338.2012.00588.x.

[116] Christensen, C. M., \& Raynor, M. E. (2003). The Innovator's Solution: Creating and Sustaining Successful Growth. Harvard Business School Press: Boston, MA.

[117] Fahrudi, A. N. L. I. (2020). Alleviating poverty through social innovation. Australasian Accounting, Business and Finance Journal, 14(1 Special Issue), 71-78. doi:10.14453/aabfj.v14i1.7.

[118] George, G., Mcgahan, A. M., \& Prabhu, J. (2012). Innovation for Inclusive Growth: Towards a Theoretical Framework and a Research Agenda. Journal of Management Studies, 49(4), 661-683. doi:10.1111/j.1467-6486.2012.01048.x.

[119] O.E.C.D. (2015). Scaling up inclusive innovations. In Innovation Policies for Inclusive Growth, OECD Publications. doi:10.1787/9789264229488-2-en.

[120] Lubberink, R., Blok, V., van Ophem, J., van der Velde, G., \& Omta, O. (2018). Innovation for Society: Towards a Typology of Developing Innovations by Social Entrepreneurs. Journal of Social Entrepreneurship, 9(1), 52-78. doi:10.1080/19420676.2017.1410212. 
[121] Weyrauch, T., \& Herstatt, C. (2017). What is frugal innovation? Three defining criteria. Journal of Frugal Innovation, 2(1), 117. doi:10.1186/s40669-016-0005-y.

[122] Prahalad, C. K. (2005). The Fortune at the Bottom of the Pyramid: Eradicating Poverty through Profits. In International Journal of Productivity and Performance Management 54(2). Wharton School Publishing. doi:10.1108/ijppm.2005.07954bae.003.

[123] Yunus, M. (2010). Building social business: the new kind of capitalism that serves humanity's most pressing needs. In Choice Reviews Online (Vol. 48, Issue 01, pp. 48-0381-48-0381). doi:10.5860/choice.48-0381.

[124] Pilková, A., Jančovičová, Z., \& Kovačičová, Z. (2016). Inclusive Entrepreneurship in Visegrad4 Countries. Procedia - Social and Behavioral Sciences, 220, 312-320. doi:10.1016/j.sbspro.2016.05.504.

[125] Markussen, T. (2017). Disentangling ‘the social' in social design's engagement with the public realm. CoDesign, 13(3), 160174. doi:10.1080/15710882.2017.1355001.

[126] Reficco, E., Layrisse, F., \& Barrios, A. (2021). From donation-based NPO to social enterprise: A journey of transformation through business-model innovation. Journal of Business Research, 125, 720-732. doi:10.1016/j.jbusres.2020.01.031.

[127] Carvalho, J. M. S., \& Jonker, J. (2015). Creating a Balanced Value Proposition: Exploring the Advanced Business Creation Model. The Journal of Applied Management and Entrepreneurship, 20(2), 49-64. doi:10.9774/gleaf.3709.2015.ap.00006.

[128] Carvalho, J. M. S., \& Sousa, C. A. A. Social entrepreneurship, sustainability, and tetrad-value theory. Global Cleaner Production and Sustainable Consumption Conference, 1-4.

[129] Magretta, J. “Why business models matter.” Harvard Bus. Rev. 80 (2002): 86-92.

[130] Seddon, P. B., \& Freeman, P. (2004). The Case for Viewing Business Models as Abstractions of Strategy. Communications of the Association for Information Systems, 13, 427-442. doi:10.17705/1cais.01325.

[131] Teece, D. J. (2010). Business models, business strategy and innovation. Long Range Planning, 43(2-3), 172-194. doi:10.1016/j.lrp.2009.07.003.

[132] Zott, C., Amit, R., \& Massa, L. (2011). The business model: Recent developments and future research. Journal of Management, 37(4), 1019-1042. doi:10.1177/0149206311406265.

[133] Elkington, J. (1999). Cannibals with forks: the triple bottom line of 21st century business. In Choice Reviews Online 36(07), 36-3997-36-3997. doi:10.5860/choice.36-3997.

[134] Carvalho, J. M. S., \& Sousa, C. A. A. (2018). Is psychological value a missing building block in societal sustainability? Sustainability (Switzerland), 10(12), 4550. doi:10.3390/su10124550.

[135] Bandura, A. (1977). Self-efficacy: Toward a unifying theory of behavioral change. Psychological Review, 84(2), 191-215. doi:10.1037/0033-295X.84.2.191.

[136] Anderson, N., Costa, A. C., \& Salgado, J. F. (2012). Sustainability and Industrial, Work, and Organizational Psychology: Globalization, Contribution, and Psychological Sustainability. Industrial and Organizational Psychology, 5(4), 487-490. doi:10.1111/j.1754-9434.2012.01484.x.

[137] Cohen, B., \& Winn, M. I. (2007). Market imperfections, opportunity and sustainable entrepreneurship. Journal of Business Venturing, 22(1), 29-49. doi:10.1016/j.jbusvent.2004.12.001.

[138] Horelli, L. (2010). Sustaining Everyday Life through Psychological Presence; Time and Space. In Proceedings of the Sustaining Everyday Life Conference: April 22-24 2009; Campus Norrköping; Sweden (No. 038, pp. 9-26). Linköping University Electronic Press.

[139] Muralidharan, E., \& Pathak, S. (2018). Sustainability, transformational leadership, and social entrepreneurship. Sustainability (Switzerland), 10(2), 567. doi:10.3390/su10020567.

[140] OECD. Publishing, \& Organisation for Economic Co-operation and Development. (2013). OECD guidelines on measuring subjective well-being. OECD publishing.

[141] WHO - World Health Organization. "Preamble to the Constitution of the World Health Organization as adopted by the International Health Conference, New York, NY, USA, 19-22 June 1946” (1948). Signed on 22 July 1946 by the Representatives of 61 States (Official Records of the World Health Organization, no. 2, p. 100) and Entered into Force on 7 April 1948; World Health Organization: Geneva, Switzerland.

[142] Fiorentini, G. (2006) "Impresa sociale e sussidiarietà". Franco Angeli: Milano, Italy.

[143] Mutis, J., and J. Ricart. (2008) "Innovación en modelos de negócio: La base de la pirámide como campo de experimentación [Innovation in Business Models. The Base of the Pyramid a new field of experimentation].” Universia Business Review, 18, 10-27. 
[144] Freeman, R. E. (1984). Strategic management: A stakeholder approach. In Strategic Management: A Stakeholder Approach doi:10.1017/CBO9781139192675.

[145] Austin, J. E., \& Seitanidi, M. M. (2012). Collaborative Value Creation: A Review of Partnering Between Nonprofits and Businesses: Part I. Value Creation Spectrum and Collaboration Stages. Nonprofit and Voluntary Sector Quarterly, 41(5), 726758. doi:10.1177/0899764012450777.

[146] Austin, J. E., \& Seitanidi, M. M. (2012). Collaborative Value Creation: A Review of Partnering Between Nonprofits and Businesses. Part 2: Partnership Processes and Outcomes. Nonprofit and Voluntary Sector Quarterly, 41(6), 929-968. doi:10.1177/0899764012454685.

[147] Chatterjee, S. (2013). Simple rules for designing business models. California Management Review, 55(2), 97-124. doi:10.1525/cmr.2013.55.2.97.

[148] Porter, M. E., \& Kramer, M. R. (2011). Creating shared value. Harvard Business Review, 89(1-2), 62-77. doi:10.32591/coas.ojss.0201.04037b.

[149] Carroll, A. B. (2017). A three-dimensional conceptual model of corporate performance. Corporate Social Responsibility, 4, 37-45. doi:10.5465/amr.1979.4498296.

[150] Maignan, I., Ferrell, O. C., \& Hult, G. T. M. (1999). Corporate citizenship: Cultural antecedents and business benefits. Journal of the Academy of Marketing Science, 27(4), 455-469. doi:10.1177/0092070399274005.

[151] Davis, J. H., Schoorman, F. D., \& Donaldson, L. (1997). Toward a Stewardship Theory of Management. The Academy of Management Review, 22(1), 20. doi:10.2307/259223.

[152] Grayson, D., Rodriguez, M. A., Lemon, M., Jin, Z., Slaughter, S., \& Tay, S. (2008). A new mindset for corporate sustainability (pp. 1-27). Available online from: https://www.cisco.com/c/dam/global/en_uk/assets/pdfs/A_mind_set_for_corporate_ sustainability .pdf (accessed 12 July 2021)

[153] Hayek, M., Williams, W. A., Taneja, S., \& Salem, R. (2015). Effective Succession of Social Entrepreneurs: A Stewardshipbased Model. The Journal of Applied Management and Entrepreneurship, 20(2), 93-111. doi:10.9774/gleaf.3709.2015.ap.00008.

[154] Carvalho, J., Jonker, J., Dentchev, N., Carvalho, J., Jonker, J., \& Dentchev, N. (2014). What's in a word? An Exploration of the changes in meaning of corporate social responsibility over the last century with an emphasis on the last decades. In D. Turker, H. Toke, \& C. Altuntas (Eds.), Contemporary Issues in Corporate Social Responsibility (pp. 1-18). Plymouth, U.K.

[155] McWilliams, A., \& Siegel, D. (2001). Corporate social responsibility: A theory of the firm perspective. Academy of Management Review, 26(1), 117-127. doi:10.5465/AMR.2001.4011987.

[156] Jennings, P. D., \& Zandbergen, P. A. (1995). Ecologically Sustainable Organizations: An Institutional Approach. The Academy of Management Review, 20(4), 1015. doi:10.2307/258964.

[157] Carroll, A. B. (1991). The pyramid of corporate social responsibility: Toward the moral management of organizational stakeholders. Business Horizons, 34(4), 39-48. doi:10.1016/0007-6813(91)90005-G.

[158] Carroll, A. B. (1999). Corporate social responsibility: Evolution of a definitional construct. Business and Society, 38(3), 268295. doi:10.1177/000765039903800303.

[159] Engelen, A., Heinemann, F., \& Brettel, M. (2009). Cross-cultural entrepreneurship research: Current status and framework for future studies. Journal of International Entrepreneurship, 7(3), 163-189. doi:10.1007/s10843-008-0035-5.

[160] Shane, S., \& Venkataraman, S. (2000). The Promise of Enterpreneurship as a Field of Research. The Academy of Management Review, 25(1), 217. doi:10.2307/259271.

[161] Antoncic, B., \& Hisrich, R. D. (2001). Intrapreneurship: Construct refinement and cross-cultural validation. Journal of Business Venturing, 16(5), 495-527. doi:10.1016/S0883-9026(99)00054-3.

[162] Muscat, E., \& Whitty, M. (2009). Social Entrepreneurship: Values-Based Leadership to Transform Business Education and Society. Business Renaissance Quarterly, 4(1), 31.

[163] Santos, F. M. (2012). A Positive Theory of Social Entrepreneurship. Journal of Business Ethics, 111(3), 335-351. doi:10.1007/s10551-012-1413-4.

[164] Mair, J., \& Martí, I. (2006). Social entrepreneurship research: A source of explanation, prediction, and delight. Journal of World Business, 41(1), 36-44. doi:10.1016/j.jwb.2005.09.002.

[165] Short, J. C., Moss, T. W., \& Lumpkin, G. T. (2009). Research in social entrepreneurship: past contributions and future opportunities. Strategic Entrepreneurship Journal, 3(2), 161-194. doi:10.1002/sej.69.

[166] Sullivan Mort, G., Weerawardena, J., \& Carnegie, K. (2003). Social entrepreneurship: towards conceptualisation. International Journal of Nonprofit and Voluntary Sector Marketing, 8(1), 76-88. doi:10.1002/nvsm.202. 
[167] Lumpkin, G. T., Moss, T. W., Gras, D. M., Kato, S., \& Amezcua, A. S. (2013). Entrepreneurial processes in social contexts: How are they different, if at all? Small Business Economics, 40(3), 761-783. doi:10.1007/s11187-011-9399-3.

[168] Alt, E., \& Geradts, T. (2019). Social intrapreneurship: Unique challenges and opportunities for future research. In Atinc (Ed.), 79th Annual Meeting of the Academy of Management 2019: Understanding the Inclusive Organization, AoM 2019. doi:10.5465/AMBPP.2019.188.

[169] Davis, G., \& White, C. (2015). Changing your company from the inside out: A guide for social intrapreneurs. Harvard Business Review Press.

[170] Munshi, N. V. (2010). Value creation, social innovation, and entrepreneurship in global economies. Journal of Asia-Pacific Business, 11(3), 160-165. doi:10.1080/10599231.2010.500569.

[171] Ajzen, I., \& Fishbein, M. (1969). The prediction of behavioral intentions in a choice situation. Journal of Experimental Social Psychology, 5(4), 400-416. doi:10.1016/0022-1031(69)90033-X.

[172] Ajzen, I. (1991). The theory of planned behavior. In Organizational Behavior and Human Decision Processes (Vol. 50, Issue 2, pp. 179-211). doi:10.1016/0749-5978(91)90020-T.

[173] Shapero, A., \& Sokol, L. (1982). The social dimensions of entrepreneurship. University of Illinois at Urbana-Champaign's Academy for Entrepreneurial Leadership Historical Research Reference in Entrepreneurship.

[174] Bandura, A. (1986) “Social Foundations of Thought and Action: A Social Cognitive Theory” (1986). Prentice-Hall: Englewood Cliffs, NJ, USA.

[175] Fine, S., Meng, H., Feldman, G., \& Nevo, B. (2012). Psychological Predictors of Successful Entrepreneurship in China: An Empirical Study. International Journal of Management, 29(1), 279.

[176] Garci’a, J. C. S. (2014). Cognitive Scripts and Entrepreneurial Success. Universitas Psychologica, 13(1), $321-332$. doi:10.11144/Javeriana.UPSY13-1.cses.

[177] Garci’a, J. C. S., Boada-Grau, J., Prizmic-Kuzmica, A. J., \& Herna'ndez-Sa'nchez, B. (2014). Pyschometric Properties and the Factor Structure of the Spanish Version of the Cognitive Adaptability Scale (MAC). Universitas Psychologica, 13(1), 311320. doi:10.11144/Javeriana.UPSY13-1.ppfs.

[178] Mitchell, R. K., Busenitz, L., Lant, T., McDougall, P. P., Morse, E. A., \& Smith, J. B. (2002). Toward a Theory of Entrepreneurial Cognition: Rethinking the People Side of Entrepreneurship Research. Entrepreneurship Theory and Practice, 27(2), 93-104. doi:10.1111/1540-8520.00001.

[179] Thorgren, S., \& Omorede, A. (2018). Passionate Leaders in Social Entrepreneurship: Exploring an African Context. Business and Society, 57(3), 481-524. doi:10.1177/0007650315612070.

[180] do Paço, A. M. F., Ferreira, J. M., Raposo, M., Rodrigues, R. G., \& Dinis, A. (2011). Behaviours and entrepreneurial intention: Empirical findings about secondary students. Journal of International Entrepreneurship, 9(1), 20-38. doi:10.1007/s10843-0100071-9.

[181] Van Der Sluis, J., Van Praag, M., \& Vijverberg, W. (2008). Education and entrepreneurship selection and performance: A review of the empirical literature. Journal of Economic Surveys, 22(5), 795-841. doi:10.1111/j.1467-6419.2008.00550.x.

[182] Brockhaus, R. H., and P. S. Horwitz. “The psychology of the entrepreneur.” In The art and science of entrepreneurship (1986). D. Sexton, and R. Smilor, Eds. Ballinger Pusblishing Company: (pp. 25-48), Massachussets, USA.

[183] Smith, I. H., \& Woodworth, W. P. (2012). Developing social entrepreneurs and social innovators: A social identity and selfefficacy approach. Academy of Management Learning and Education, 11(3), 390-407. doi:10.5465/amle.2011.0016.

[184] Tajfel, H., \& Turner, J. (1979). An integrative theory of inter-group conflict. In Eds. (Ed.), The social psychology of intergroup relations (pp. 33-47). Monterey, CA, USA.

[185] Peterson, S. J., Walumbwa, F. O., Byron, K., \& Myrowitz, J. (2009). CEO positive psychological traits, transformational leadership, and firm performance in high-technology start-up and established firms. Journal of Management, 35(2), 348-368. doi: $10.1177 / 0149206307312512$.

[186] Dyer, J. H., Gregersen, H. B., \& Christensen, C. M. (2009) “The Innovators' DNA”. Harvard Business Review, 87(12), 6167.

[187] White, R. E., Thornhill, S., \& Hampson, E. (2007). A biosocial model of entrepreneurship: The combined effects of nurture and nature. Journal of Organizational Behavior, 28(4), 451-466. doi:10.1002/job.432.

[188] Benzing, C., Chu, H. M., \& Kara, O. (2009). Entrepreneurs in Turkey: A factor analysis of motivations, success factors, and problems. Journal of Small Business Management, 47(1), 58-91. doi:10.1111/j.1540-627X.2008.00262.x.

[189] Akehurst, G., Comeche, J. M., \& Galindo, M. A. (2009). Job satisfaction and commitment in the entrepreneurial SME. Small Business Economics, 32(3), 277-289. doi:10.1007/s11187-008-9116-z. 
[190] Papagiannidis, S., Li, F., Etzkowitz, H., \& Clouser, M. (2009). Entrepreneurial networks: A triple helix approach for brokering human and social capital. Journal of International Entrepreneurship, 7(3), 215-235. doi:10.1007/s10843-009-0038-x.

[191] Hartog, J., Van Praag, M., \& Van Der Sluis, J. (2010). If You Are So Smart, Why Aren’t You an Entrepreneur? Returns to Cognitive and Social Ability: Entrepreneurs versus Employees. Journal of Economics and Management Strategy, 19(4), 947989. doi:10.1111/j.1530-9134.2010.00274.x.

[192] Lazear, E. P. (2005). Entrepreneurship. Journal of Labor Economics, 23(4), 649-680. doi:10.1086/491605.

[193] Gimmon, E., \& Levie, J. (2009). Instrumental value theory and the human capital of entrepreneurs. Journal of Economic Issues, 43(3), 715-732. doi:10.2753/JEI0021-3624430307.

[194] Tool, M. R. (2007). The Theory of Instrumental Value: Extensions, Clarifications. In M. Tool (Ed.), Institutional Economics: Theory, Method, Policy (pp. 119-172). Kluwer Academic Publishers. doi:10.1007/978-0-585-29604-3_4.

[195] Rathna, K. G., \& Vijaya, T. G. (2009). Competencies of entrepreneurs and intrapreneurs: A comparative study. South Asian Journal of Management, 16(2), 28-46.

[196] Hechavarria, D. M., Renko, M., \& Matthews, C. H. (2012). The nascent entrepreneurship hub: Goals, entrepreneurial selfefficacy and start-up outcomes. Small Business Economics, 39(3), 685-701. doi:10.1007/s11187-011-9355-2.

[197] Locke, E. A., and G. Latham. “A theory of goal setting and task performance” (1990). Prentice Hall: Englewood Cliffs, New Jersey, USA.

[198] Bandura, A. (2001). Social cognitive theory: An agentic perspective. Annual Review of Psychology, 52, 1-26. doi:10.1146/annurev.psych.52.1.1.

[199] López-Núñez, M. I., Rubio-Valdehita, S., Aparicio-García, M. E., \& Díaz-Ramiro, E. M. (2020). Are entrepreneurs born or made? The influence of personality. Personality and Individual Differences, 154, 109699. doi:10.1016/j.paid.2019.109699.

[200] Bygrave, B. (2004) “The entrepreneurial process.” In The portable MBA in entrepreneurship. W. Bygrave, and A. E. Zacharkis, Eds. John Wiley \& Sons: Hoboken, (1-28), NJ, USA.

[201] Mcmullen, J. S., \& Dimov, D. (2013). Time and the entrepreneurial journey: The problems and promise of studying entrepreneurship as a process. Journal of Management Studies, 50(8), 1481-1512. doi:10.1111/joms.12049.

[202] Hindle, K., \& Senderovitz, M. (2010). Unifying the three principal contending approaches to explaining early-stage entrepreneurial decision-making and behavior. 2010 BCERC Proceedings, 30, 1-15.

[203] Fisher, G. (2012). Effectuation, causation, and bricolage: A behavioral comparison of emerging theories in entrepreneurship research. Entrepreneurship: Theory and Practice, 36(5), 1019-1051. doi:10.1111/j.1540-6520.2012.00537.x.

[204] Perrini, F., Vurro, C., \& Costanzo, L. A. (2010). A process-based view of social entrepreneurship: From opportunity identification to scaling-up social change in the case of San Patrignano. Entrepreneurship and Regional Development, 22(6), 515-534. doi:10.1080/08985626.2010.488402.

[205] Barinaga, E. (2017). Tinkering with Space: The Organizational Practices of a Nascent Social Venture. Organization Studies, 38(7), 937-958. doi:10.1177/0170840616670434.

[206] Baum, J. R., Bird, B. J., \& Singh, S. (2011). The practical intelligence of entrepreneurs: Antecedents and a link with new venture growth. Personnel Psychology, 64(2), 397-425. doi:10.1111/j.1744-6570.2011.01214.x.

[207] Lévi-Strauss, C. (1966).“The Savage Mind”. University of Chicago Press: Chicago, IL, USA.

[208] Baker, T., \& Nelson, R. E. (2005). Creating something from nothing: Resource construction through entrepreneurial bricolage. Administrative Science Quarterly, 50(3), 329-366. doi:10.2189/asqu.2005.50.3.329.

[209] Salimath, M., \& Jones III, R. (2011). Scientific entrepreneurial management: Bricolage, bootstrapping, and the quest for efficiencies. Journal of Business and Management, 17(1), 85.

[210] Winborg, J., \& Landström, H. (2001). Financial bootstrapping in small businesses: Examining small business managers' resource acquisition behaviors. Journal of Business Venturing, 16(3), 235-254. doi:10.1016/S0883-9026(99)00055-5.

[211] Harrison, R. T., Mason, C. M., \& Girling, P. (2004). Financial bootstrapping and venture development the software industry. Entrepreneurship and Regional Development, 16(4), 307-333. doi:10.1080/0898562042000263276.

[212] Blank, S. (2013). Why the lean start-up changes everything. Harvard Business Review, 91(5), 63-72.

[213] Ries, E. (2011) “The Lean Startup: How Today's Entrepreneurs Use Continuous Innovation to Create Radically Successful Businesses". Crown Business: New York, USA.

[214] Kirtley, J., \& O’Mahony, S. (2020). What is a pivot? Explaining when and how entrepreneurial firms decide to make strategic change and pivot. Strategic Management Journal. doi:10.1002/smj.3131. 
[215] Sarasvathy, S. D. (2001). Causation and Effectuation: Toward a Theoretical Shift from Economic Inevitability to Entrepreneurial Contingency. The Academy of Management Review, 26(2), 243. doi:10.2307/259121.

[216] Sarasvathy, S. D., \& Venkataraman, S. (2011). Entrepreneurship as Method: Open Questions for an Entrepreneurial Future. Entrepreneurship: Theory and Practice, 35(1), 113-135. doi:10.1111/j.1540-6520.2010.00425.x.

[217] Rapp, D. J., \& Olbrich, M. (2020). On entrepreneurial decision logics under conditions of uncertainty: an attempt to advance the current debate. Journal of Innovation and Entrepreneurship, 9(1), 21. doi:10.1186/s13731-020-00131-7.

[218] Moroz, P. W., \& Hindle, K. (2012). Entrepreneurship as a Process: Toward Harmonizing Multiple Perspectives. Entrepreneurship: Theory and Practice, 36(4), 781-818. doi:10.1111/j.1540-6520.2011.00452.x.

[219] Mazzocchi, S. (2004). Open Innovation: The New Imperative For Creating and Profiting From Technology. In Innovation (Vol. 6, Issue 3). Harvard Business School Press. doi:10.5172/impp.2004.6.3.474.

[220] Bogers, M., Zobel, A. K., Afuah, A., Almirall, E., Brunswicker, S., Dahlander, L., Frederiksen, L., Gawer, A., Gruber, M., Haefliger, S., Hagedoorn, J., Hilgers, D., Laursen, K., Magnusson, M. G., Majchrzak, A., McCarthy, I. P., Moeslein, K. M., Nambisan, S., Piller, F. T., ... Ter Wal, A. L. J. (2017). The open innovation research landscape: established perspectives and emerging themes across different levels of analysis. Industry and Innovation, 24(1), 8-40. doi:10.1080/13662716.2016.1240068.

[221] Balta, M. E., Darlington, C., Smith, S. L., \& Cornelius, N. (2012). Entrepreneurial Orientation and Social Innovation Practices in Social Enterprises: The Rhetoric and Reality. International Journal of Business and Social Science, 3(17), 24-32.

[222] Young, W., \& Tilley, F. (2006). Can businesses move beyond efficiency? The shift toward effectiveness and equity in the corporate sustainability debate. Business Strategy and the Environment, 15(6), 402-415. doi:10.1002/bse.510.

[223] Jo, H., \& Harjoto, M. A. (2011). Corporate Governance and Firm Value: The Impact of Corporate Social Responsibility. Journal of Business Ethics, 103(3), 351-383. doi:10.1007/s10551-011-0869-y.

[224] Son, H., Lee, J., \& Chung, Y. (2018). Value creation mechanism of social enterprises in manufacturing industry: Empirical evidence from Korea. Sustainability (Switzerland), 10(1), 46. doi:10.3390/su10010046.

[225] Glavas, A. (2016). Corporate social responsibility and employee engagement: Enabling employees to employ more of their whole selves at work. Frontiers in Psychology, 7(MAY), 796. doi:10.3389/fpsyg.2016.00796.

[226] Carree, M. A., \& Thurik, A. R. (2008). The lag structure of the impact of business ownership on economic performance in OECD countries. Small Business Economics, 30(1), 101-110. doi:10.1007/s11187-006-9007-0.

[227] Van Praag, C. M., \& Versloot, P. H. (2008). The economic benefits and costs of entrepreneurship: A review of the research. Foundations and Trends in Entrepreneurship, 4(2), 65-154. doi:10.1561/0300000012.

[228] European Commission. (2013). “Guide to Social Innovation”. European Commission: Brussels, Belgium.

[229] Clark, C., \& Brennan, L. (2012). Entrepreneurship with social value: A conceptual model for performance measurement. Academy of Entrepreneurship Journal, 18(2), 17-40.

[230] Faludi, J. (2020). How to Create Social Value through Digital Social Innovation? Unlocking the Potential of the Social Value Creation of Digital Start-Ups. Journal of Social Entrepreneurship. doi:10.1080/19420676.2020.1823871.

[231] Kaplan, R. S., \& Norton, D. P. (2005). The balanced scorecard: Measures that drive performance. Harvard Business Review, 83(7-8), 71-79.

[232] McLoughlin, J., Kaminski, J., Sodagar, B., Khan, S., Harris, R., Arnaudo, G., \& Mc Brearty, S. (2009). A strategic approach to social impact measurement of social enterprises. Social Enterprise Journal, 5(2), $154-178$. doi:10.1108/17508610910981734.

[233] Munn, Z., Peters, M. D. J., Stern, C., Tufanaru, C., McArthur, A., \& Aromataris, E. (2018). Systematic review or scoping review? Guidance for authors when choosing between a systematic or scoping review approach. BMC Medical Research Methodology, 18(1), 143. doi:10.1186/s12874-018-0611-x.

[234] Arksey, H., \& O’Malley, L. (2005). Scoping studies: Towards a methodological framework. International Journal of Social Research Methodology: Theory and Practice, 8(1), 19-32. doi:10.1080/1364557032000119616.

[235] Winter, R. (2008). Design science research in Europe. European Journal of Information Systems, 17(5), 470-475. doi:10.1057/ejis.2008.44. 